Водные биоресурсы и среда обитания

2018, том 1, номер 2, с. 70-94

http://journal.azniirkh.ru, www.azniirkh.ru ISSN 2618-8147 print, ISSN 2619-1024 online

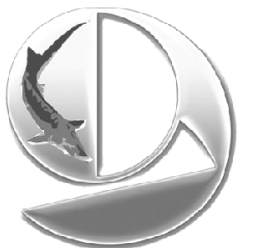

Aquatic Bioresources \& Environment

2018, vol. 1, no. 2, pp. 70-94

http://journal.azniirkh.ru, www.azniirkh.ru

ISSN 2618-8147 print, ISSN 2619-1024 online

\title{
Международное сотрудничество
}

УДК 504.4.062.2:341.24(269)

\section{КОНВЕНЦИЯ О СОХРАНЕНИИ МОРСКИХ ЖИВЫХ РЕСУРСОВ АНТАРКТИКИ И ПРОБЛЕМЫ УПРАВЛЕНИЯ}

\author{
(C) 2018 Н. Н. Кухарев, А. К. Зайцев \\ Азовский научно-исследовательский институт рыбного хозяйства, \\ Керченский филиал, Керчь 298300, Россия \\ E-mail:kuharev_n_n@azniirkh.ru
}

\begin{abstract}
Аннотация. В 1982 г. на основе Антарктической конвенции создана международная организация Антарктическая комиссия (АНТКОМ), которая в соответствии с Конвенцией ООН по морскому праву является региональной организацией по регулированию рыболовства с расширенными полномочиями по сохранению экосистемы Антарктики. АНТКОМ управляет промыслом с помощью Мер по сохранению (MC), разрабатываемых Научным комитетом с учетом результатов научных наблюдений и программ, моделирования и рекомендаций рабочих групп. Меры принимаются делегациями стран-членов ежегодно и только консенсусом. Современный вылов в Антарктике составляет 279 тыс. т (2016 г.), из них 260 тыс. т приходится на криль, 12 тыс. т составляет патагонский клыкач, 4 тыс. т - антарктический клыкач, 0,6 тыс. т - щуковидная белокровка, 2,4 тыс. т - прилов (макрурусы и антимора). Промысел ведут (по убывающей) Норвегия, КНР, Республика Корея, Украина, Франция, Чили, Австралия, Великобритания, Новая Зеландия, Россия, Испания, ЮАР, Уругвай, Япония. Все участки промысла находятся в секторах территориальных притязаний государств региона. АНТКОМ применяет предосторожный подход, основанный на моделировании, предположениях и допущениях. На содержание Мер влияют более 20 сотрудничающих с АНТКОМ общественных организаций: Коалиция по Антарктике и Южному океану, Комитет по охране окружающей среды, Международный союз охраны природы и пр. Современная система управления АНТКОМ ориентирована на минимизацию промысла и декларативную деятельность по сохранению экосистемы. С 1989 по 2016 г. страны-члены АНТКОМ закрыли промыслы на 70 \% площади продуктивных районов, ограничили до минимума вылов ледяных рыб и антарктического клыкача, запретили промысел нототений, электроны Карлсберга и др. С 2005 г. некоторые государствачлены АНТКОМ (Великобритания, США, Австралия, Новая Зеландия, Франция), ссылаясь на рекомендации Всемирного Саммита в Йоханнесбурге (2002 г.), навязывали АНТКОМ программы создания сети морских охраняемых районов (МОР) площадью в несколько млн кв. км в акваториях, прилегающих к секторам их территориальных притязаний в Антарктике, с передачей МОР под их собственное управление. Предполагалось создание МОР под управлением Новой Зеландии в районе моря Росса, где ведется промысел антарктического клыкача, и в прилегающей акватории, включая участок Антарктического циркумполярного течения. Россия, Украина и ряд других государств блокировали создание этого МОР ввиду отсутствия научных обоснований, а передача акваторий открытых вод Мирового океана под управление какого-либо государства не предусмотрена Конвенцией ООН по морскому праву. Компромисс был достигнут путем создания в 2016 г. МОР под управлением АНТКОМ с условием выделения участка
\end{abstract}


для промысла с выловом на уровне прошлых лет. С учетом достигнутого компромисса АНТКОМ развивает идеи создания сети МОР вокруг Антарктического континента с возможностью ограниченного промысла в них. Однако государства-члены АНТКОМ, создав МОР в открытых водах Антарктики и намереваясь каким-то образом его охранять, тем самым вышли за правовые пределы Антарктической конвенции, которая не предусматривает охрану и защиту акваторий и биоты, в т. ч. путем создания МОР. Изменение регуляторной политики АНТКОМ в сторону создания сети МОР в Антарктике ориентировано на положительную реакцию международных неправительственных природоохранных организаций и заинтересованной мировой общественности. При этом существуют обоснованные сомнения в способности МОР поддерживать разнообразие видов, функциональные роли и биомассу гидробионтов, в частности в регионах с глубоким и длительным антропогенным воздействием, а также в условиях таких интенсивных гидрологических процессов, как Антарктическое циркумполярное течение. Не приходится сомневаться, что в случае реализации планов сторонников МОР по закрытию большей части акватории Антарктики подобными охраняемыми районами уловы в них придется сводить к минимуму и какое-либо развитие рыболовства в Антарктике станет невозможным, а ее огромные биоресурсы станут недоступными для человечества.

Ключевые слова: Антарктика, АНТКОМ, экосистема, предосторожный подход, Меры по сохранению, управление промыслом

\title{
THE CONVENTION FOR THE CONSERVATION OF ANTARCTIC MARINE LIVING RESOURCES AND MANAGEMENT PROBLEMS
}

\author{
N. N. Kukharev, A. K. Zaytsev \\ Azov Sea Research Fisheries Institute, Kerch Branch, Kerch 298300, Russia \\ E-mail:kuharev_n_n@azniirkh.ru
}

\begin{abstract}
In 1982, based on the Antarctic Convention, the international organization - Commission for the Conservation of Antarctic Marine Living Resources (CCAMLR) — was founded, which is, according to the United Nations Convention on the Law of the Sea, a regional organization, aimed at fisheries management and invested with enhanced authority on the issues of the Antarctic ecosystem conservation. CCAMLR regulates fisheries by implementing the Conservation Measures (CMs). They are developed by the Scientific Committee with regard to results of scientific observations and programs, models and simulations, and recommendations from the Working Groups. The Measures are adopted by the delegations from member states annually and only after consensus of opinions. Current yield from fishing and harvesting operations in the Antarctic amounts to 279,000 t (2016), including 260,000 t of krill, 12,000 t of the Patagonian toothfish, 4,000 t of the Antarctic toothfish, $600 \mathrm{t}$ of the mackerel icefish, and 2,400 $\mathrm{t}$ of by-catch (macrouruses and antimora). Fishing and harvesting operations are carried out (in descending order) by Norway, the People's Republic of China, the Republic of Korea, Ukraine, France, Chile, Australia, Great Britain, New Zealand, Russia, Spain, the Republic of South Africa, Uruguay, Japan. All fishing and harvesting sites are located in the areas, covered by territorial claims of the states of the region. So far CCAMLR has been applying precautionary approach instead, in which precautionary criteria are derived from modeling, inferences and assumptions. Over 20 non-governmental organizations, collaborating with CCAMLR, influence the content of the Measures: Antarctic and Southern Ocean Coalition, Environmental Protection Committee, International Union for Conservation of Nature and Natural Resources, etc. CCAMLR current system of management is basically politically motivated, oriented on minimization of fishing and harvesting operations, and proclamatory conservation of the ecosystem. From 1989 to 2017, CCAMLR member states agreed to shut down fishing operations in $70 \%$ of productive areas, limited fishing operations on icefishes and the Antarctic toothfish down to minimum, banned fishing of cod icefishes (notothens), Electron subantarctic lanternfish and other species. Since 2005, on the pretext of the recommendations of the World Summit on Sustainable Development in Johannesburg (2002), the programs on creating of the Marine Protected Areas (MPAs) network in the Antarctic were imposed on CCAMLR by its member states - Great Britain, the USA, Australia, New Zealand, and France. Those MPAs were meant to cover the area of millions of sq. $\mathrm{km}$, to be located in the waters, adjacent to the sectors of their territorial claims in the Antarctic, and to be put under their own control. It was intended to create an MPA under the control of New Zealand, located in the Ross Sea Region, where fishing operations on the Antarctic toothfish are carried out, and in the adjacent waters, including the
\end{abstract}


section of the Antarctic Circumpolar Current. Russia, Ukraine and several other countries vetoed creation of this MPA, due to the absence of scientific substantiations for it, and also for the reason that such handover of the sites in the open seas of the World Ocean under the control of any state is not stipulated by the Antarctic Convention. A compromise was reached in 2016 by means of creation of a new MPA under the CCAMLR authority, under the condition that there would be assigned a site, where fishing operations can be carried out, yielding catch on the level with the previous years. Thus, the conclusion can be drawn that CCAMLR is developing the ideas of creating the MPA network around Antarctica, where fishing operations could be limited. However, by creating the MPA in the Antarctic open seas and intending to protect it, CCAMLR member states exceeded the legal bounds of the Antarctic Convention, which does not provide for conservation and protection of aquatic areas and biota, including creation of MPAs. Change in CCAMLR regulatory policy to creation of the MPA network in the Antarctic is aimed at positive response of international non-governmental conservational organizations and global community. That being said, there exist well-grounded doubts that an MPA makes it possible to maintain species diversity, functional roles and biomass of hydrobionts, particularly in the regions with continuous anthropogenic pressure, as well as under the conditions of such intense hydrological processes as the Antarctic Circumpolar Current. It seems obvious that, in case the plans of the CCAMLR member states (the MPA supporters) on covering the major part of the Antarctic waters with such MPAs are realized, the catches will have to be brought down to minimum, and any fisheries development in the Antarctic will be considered impossible; its vast biological resources will be unavailable for humanity.

Keywords: Antarctic, CCAMLR, ecosystem, precautionary approach, Conservation Measures, fishery management

\section{Сокращения}

AHTKOM (CCAMLR) - Комиссия по сохранению морских живых ресурсов Антарктики, Антарктическая комиссия (Commission for the Conservation of Antarctic Marine Living Resources)

АЧА - Антарктическая часть Атлантики

АЧИО - Антарктическая часть Индийского океана

АЧТО - Антарктическая часть Тихого океана

Антарктическая Конвенция - Конвенция о сохранении морских живых ресурсов Антарктики

ИЭЗ - исключительная экономическая зона

Государства КСДА - государства Консультативные стороны Договора об Антарктике 1959 г., участники Консультативных Совещаний Договора об Антарктике

КСДА - Консультативные Совещания Договора об Антарктике

КООС - Комитет по охране окружающей среды Договора об Антарктике

МC - Меры АНТКОМ по сохранению

МКК - Международная китобойная комиссия (International Whaling Commission - IWC)

MOP - морской охраняемый район

ОДУ - общий допустимый улов
СКАР - Научный комитет по антарктическим исследованиям

ASOC - Коалиция Антарктики и Южного океана (глобальная коалиция природоохранных неправительственных организаций, насчитывающая более 150 членов в 40 странах мира)

AOA - Антарктический Альянс (коалиция ведущих мировых организаций и фондов по защите дикой природы, в которую входит более 30 организаций, в т. ч. «Гринпис» и Всемирный фонд дикой природы)

NAFO (Northwest Atlantic Fisheries Organization) - Организация по рыболовству в северозападной части Атлантического океана, НАФО

NEAFC (North East Atlantic Fisheries Commission) - Комиссия по рыболовству в северо-восточной части Атлантического океана, НЕАФК

SPRFMO (South Pacific Regional Fisheries Management Organisation) - Региональная организация по регулированию рыболовства в южной части Тихого океана

CEMP (CCAMLR's Ecosystem Monitoring Programme) - Программа АНТКОМ по экосистемному мониторингу

\section{ВВЕДЕНИЕ}

С конца XX - начала XXI века проблемы сохранения экосистемы Антарктики все чаще становят- 
ся объектом внимания исследователей и мировых средств массовой информации, озабоченных климатическими изменениями на планете, усилением антропогенного воздействия на морские экосистемы, снижением видового многообразия и т. п. Среди основных угроз экосистеме Антарктики называют рыболовство, незаконный, несообщаемый и нерегулируемый (НHН) промысел, инвазию чужеродных видов, изменение климата, антропогенное загрязнение, в т. ч. последствия деятельности полярных станций и транспортных операций, туризма, иную деятельность человека в Антарктике [1-5].

В вопросах изучения и сохранения экосистемы Антарктики центральное место занимает АНТКОМ - международная организация, созданная по инициативе и усилиями государств Консультативных сторон Договора об Антарктике 1959 г. Это единственная организация, регулирующая промысел в водах Антарктики и одновременно занимающаяся вопросами сохранения уникальной антарктической экосистемы. Деятельность этой организации, а фактически - согласованная деятельность государствчленов АНТКОМ по управлению ресурсами и промыслом, основана на широком обмене научной информацией на международных совещаниях и симпозиумах, на результатах совместных экспедиционных исследований, общих публикациях и т. п. В настоящей работе представлены краткие сведения об истории и современной деятельности АНТКОМ в области управления ресурсами и промыслом.

О подготовке и принятии Конвенции о сохранении морских живых ресурсов Антарктики (Антарктической конвенции)

Разработка Антарктической конвенции была обусловлена интенсивным развитием международного рыболовства в Антарктике в конце 1960-х начале 1970-х гг. Причиной интереса к биоресурсам Антарктики стала угроза введения в этот период 200-мильных рыболовных и исключительных экономических зон в традиционных промысловых районах Европы, Африки, Северной и Южной Америк. В связи с этим СССР, имевший развитое экспедиционное рыболовство, и другие государства с давними рыболовными традициями начали развивать промысел в открытых водах Мирового океана, в т. ч. в Антарктике.

В 1961-1964 гг. в экспедициях АтлантНИРО и ВНИРО в АЧА был выполнен успешный поиск и исследована возможность тралового промысла криля и нототений. В 1966 г. в АЧА (район о. Южная Георгия) советские крупнотоннажные суда начали первый в истории Антарктики широкомасштабный траловый промысел мраморной нототении Notothenia rossii. Тем самым было положено начало освоения рыбных биоресурсов Антарктики. В 1974 г. советский рыболовный флот приступил к промыслу антарктического криля в АЧА, а японский флот — в АЧИО [6]. С 1977 г. к промыслу в Антарктике присоединялись суда под флагами Польши, Германии, Республики Корея, Франции, Чили и др. С 1966 по 1978 г. вылов в Антарктике увеличился с 1 тыс. т до 457 тыс. т. Наиболее стремительно развивался промысел криля: если в 1974 г. общий вылов составил 20 тыс. т, то в 1978 г. он достиг 137 тыс. т, а в 1979 г. - 330 тыс. т, при этом более 80 \% пришлось на советский вылов $[6,7]$ (рис. 1).

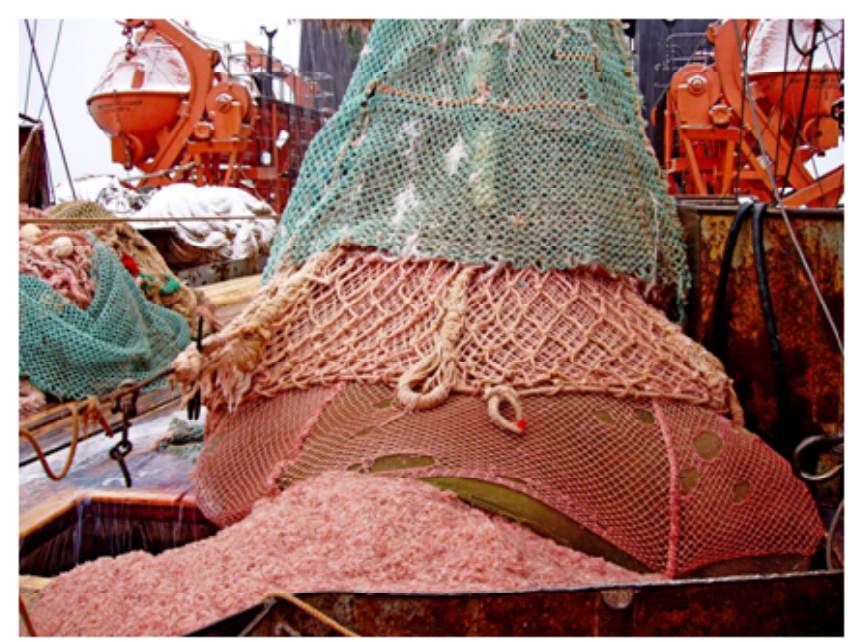

Рис. 1. Улов антарктического криля Euphausia superba в АЧА, подрайон 48.2 Южные Оркнейские острова. РКТ-С «Конструктор Кошкин», Украина, 2006 г. Фото Н.Н. Жука

Fig. 1. The Antarctic krill Euphausia superba catch in the Atlantic Antarctic, subarea 48.2, the South Orkney Islands. Krill-fishing canner freezer supertrawler “Konstruktor Koshkin”, Ukraine, 2006. Photo by N.N. Zhuk

В тот период каждое государство регулировало вылов своих судов в соответствии с внутренним законодательством, однако в государствах с высоким уровнем рыбохозяйственных исследований, в первую очередь в СССР, росло понимание необходимости кооперирования усилий по сохранению антарктической экосистемы. Своим появлением Антарктическая конвенция во многом обязана успешному выполнению в 1957-1958 гг. грандиоз- 
ного международного научного проекта - Международного геофизического года (МГГ). В ходе его проведения усилиями заинтересованных государств был создан Специальный комитет по антарктическим исследованиям, преобразованный впоследствии в СКАР - Научный Комитет по изучению Антарктики (The Scientific Committee on Antarctic Research, SCAR). Успешное комплексное сотрудничество государств в ходе проведения МГГ в Антарктике, в сочетании с территориальными притязаниями ряда стран на территорию Антарктиды и прилегающие акватории, указало на необходимость закрепления за Антарктикой особого международно-правового статуса. Страны, наиболее активно проводившие исследования в антарктических экспедициях, в первую очередь СССР и США, и отвергавшие территориальные притязания в Антарктике, после завершения МГГ начали вести переговоры о будущем Антарктики как о регионе мира и науки, который принадлежал бы всему человечеству [8, 9]. В октябре-ноябре 1959 г., в ходе работы Вашингтонской конференции, при активном участии СССР заинтересованные государства разработали и 1 декабря 1959 г. подписали бессрочный Договор об Антарктике - глобальный международный документ, впервые объявивший огромный регион к югу от $60^{\circ}$ ю. ш. зоной мира, международного сотрудничества и науки [3]. Договор об Антарктике считают первым международным соглашением по контролю над вооружениями, котрое было заключено в ходе «холодной войны», предотвратило географическое распространение ядерного оружия, объявило в Антарктике свободу научно-исследовательской деятельности, обмена информацией и сотрудничества и заморозило территориальные притязания [8, 10].

Договор об Антарктике подписали 12 государств, у которых в 1957-1958 гг. были свои полярные станции в Антарктике, так называемые первоначальные участники - Консультативные стороны Договора об Антарктике (Австралия, Аргентина, Бельгия, Великобритания, Новая Зеландия, Норвегия, СССР, США, Франция, Чили, Южно-Африканский Союз, Япония). Договор вступил в силу 23 июня 1961 г. Таким образом, начавшееся в 1961 г. интенсивное развитие рыбохозяйственных исследований, а в 1966-1974 гг. международного тралового промысла, в Антарктике проходило в условиях действующего Договора об Антарктике 1959 г. Все более расширявшаяся промысловая деятельность в
Антарктике постоянно находилась в центре внимания государств КСДА, осуществлявших в 19601970-е гг. обширные исследовательские программы на Антарктическом материке. В ходе регулярного форума, именуемого Консультативным Совещанием по Договору об Антарктике, государства КСДА рассматривали и формулировали своим правительствам рекомендации по содействию принципам и целям Договора, в т. ч. по сохранению морской биоты Антарктики.

К концу 1970-х - началу 1980-х гг. интенсивный промысел шел на всех акваториях Антарктики, максимума своего развития он достиг в АЧА и АЧИО. В этот период основными объектами пелагического тралового лова были антарктический криль Euphausia superba, добывавшиеся донными тралами мраморная нототения Notothenia rossii, серая нототения, или сквама Lepidonotothen squamifrons, патагонский клыкач Dissostichus eleginoides, зеленая нототения Notothenia gibberifrons, патагонская нототения Patagonotothen brevicauda, щуковидная белокровка, или ледяная рыба Гуннара Champsocephalus gunnari, георгианская, или темная, белокровка Pseudochaenichthys georgianus, крокодиловая белокровка Chaenocephalus aceratus. При этом основу уловов составлял криль, доля вылова рыбы варьировала в пределах 20-35\% от общего вылова [6].

По этой причине уже во второй половине 1970-х гг. государства КСДА были обеспокоены стремительным развитием советского донного тралового промысла в АЧА и АЧИО и полученными высокими уловами донных рыб - мраморной нототении Notothenia rossii и ледяной рыбы Champsocephalus gunnari. Особое беспокойство вызвал быстрый рост вылова криля - ключевого звена в пищевой цепи экосистемы Антарктики, вылов которого с 1977 по 1979 г. вырос с 91 до 477 тыс. т $[6,11]$.

В 1977 г. государствами КСДА при поддержке СКАР была создана исследовательская программа «Биологические исследования морских систем и запасов Антарктики» (БИОМАСС), которая ставила целью «добиться более глубокого понимания структуры и динамики морской экосистемы Антарктики в качестве основы для будущего управления потенциальными живыми ресурсами». В течение 8 лет проведения программы собирались данные по взаимосвязям основных компонентов морской экосистемы разных уровней, от криля и рыб до их 
потребителей, включая наземных хищников и птиц, по влиянию на них факторов среды и т. п. В 1981 г. был выполнен Международный эксперимент БИОМАСС (FIBEX) по акустической оценке запасов криля как ключевого вида в морской экосистеме Антарктики, в котором приняли участие и советские исследовательские суда $[12,13]$.

В течение 1978-1980 гг., одновременно с началом экосистемных исследований в регионе, государства КСДА при участии СКАР разработали Конвенцию о сохранении морских живых ресурсов Антарктики в ответ на неконтролируемый донный траловый промысел как угрозу быстрого роста вылова криля в условиях неопределенности знаний о его роли в экосистеме Антарктики. Исполняя Статью IX Договора об Антарктике, разработанная Конвенция определила возможность сотрудничества государств в вопросах рыболовства и сохранения биоресурсов в открытых водах Мирового океана, примыкающих к Антарктиде, т. е. в Антарктике [7].

Важной особенностью создания Антарктической конвенции является тот факт, что она разрабатывалась при участии и под существенным влиянием государств КСДА, объявивших в 1930-1940-х гг. о территориальных притязаниях на Антарктическом континенте и на прилегающей акватории. Такими государствами были Австралия, Аргентина, Великобритания, Новая Зеландия, Норвегия, Франция и Чили, претендующие в сумме примерно на $83 \%$ территории Антарктиды и прилегающие акватории. Данные притязания были заморожены Договором об Антарктике 1959 г., т. е. не приняты, но и не отменены [14].

В связи с этим Антарктическая конвенция изначально формулировалась как исключительно природоохранный документ, не предусматривавший рыболовство. По имеющимся сведениям, некоторые государства КСДА были против подготовки даже такой Конвенции, не желая отдавать под ее управление акватории, на которые они претендуют. Конвенция все же была разработана под прямым давлением СССР и США, объявивших Антарктику сферой своих интересов. Однако некоторые страны региона, не заинтересованные в использовании морских живых ресурсов Антарктики, стремились добиться включения в Антарктическую конвенцию положений, которые затруднили бы промысел этих ресурсов и сделали невозможным его дальнейшее расширение [10].
СССР и Япония, не имевшие территориальных притязаний в Антарктике и лидировавшие в антарктическом промысле, настояли на включении в Статью II Конвенции п. 2: «Для целей настоящей Конвенции термин «сохранение» включает рациональное использование». Это позволило продолжить промысел в Антарктике, но при условии соблюдения положений конвенции, направленных на сохранение биоресурсов и экосистемы Антарктики [14].

В мае 1980 г. Антарктическая конвенция была принята на Конференции по сохранению морских живых ресурсов Антарктики (г. Канберра, Австралия). Ее подписали 15 государств, 12 из них первоначальные Консультативные стороны Договора об Антарктике 1959 г. (Аргентина, Австралия, Бельгия, Великобритания, Германская Демократическая Республика, Новая Зеландия, Норвегия, Польша, СССР, США, Федеративная Республика Германия, Франция, Чили, ЮАР, Япония) [15].

Зоной действия Антарктической конвенции была определена акватория вокруг Антарктиды, ограниченная с севера антарктической конвергенцией — основной биогеографической границей экосистемы Антарктики. Уникальной особенностью антарктической экосистемы является доминирование в ее трофических отношениях антарктического криля [16].

Антарктическая конвенция стала первым международным документом, остановившим трехвековое бесконтрольное освоение биоресурсов Антарктики, когда в период с XVIII до середины XX в., в результате нерегулируемого зверобойного промысла в Атлантическом и Индоокеанском секторах, были фактически истреблены колонии тюленей южного морского слона (Miroun galeonina), кергеленских морских котиков (Arctocephalus gazella) и других ради их ценного жира (ворвани). В начале XIX века, после истребления морских слонов и котиков, началась заготовка жира пингвинов, в результате которой к середине XIX в. все стадо пингвинов у о. Южная Георгия было уничтожено, и зверобойный промысел начал переключаться на китов [17].

Антарктическая Конвенция, провозгласившая в качестве цели сохранение морских живых ресурсов Антарктики, значительно расширила общепринятое содержание термина «морские живые ресурсы», причислив к ним «...популяции плавниковых рыб, моллюсков, ракообразных и всех других видов живых организмов, включая птиц, обитающих к югу от антарктической конвергенции» (рис. 2). 


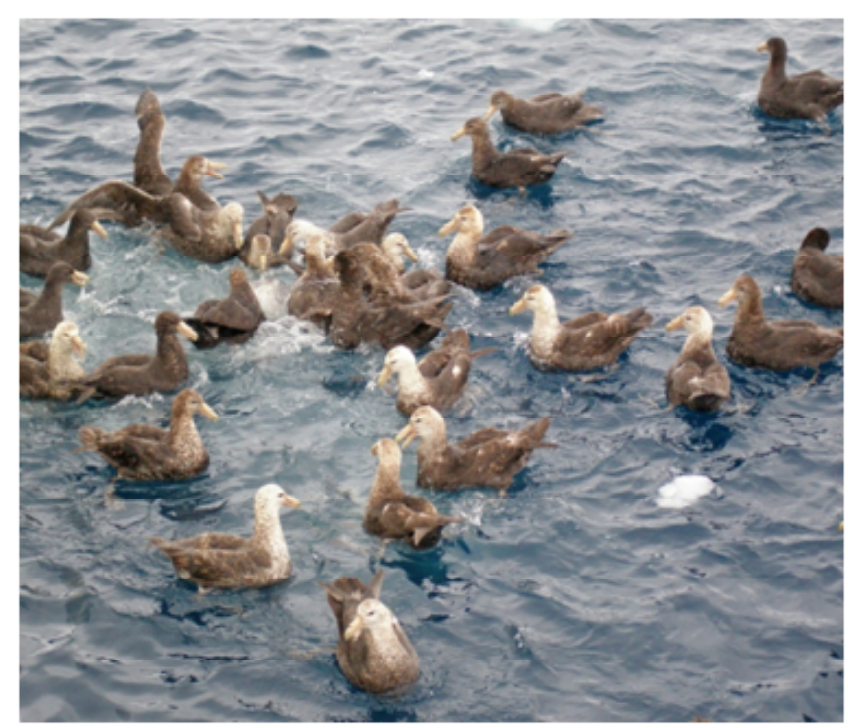

Рис. 2. Представители орнитофауны Антарктики - южный гигантский буревестник (Macronectes giganteus) в море Содружества, февраль 2007 г. Фото Н.Н. Кухарева

Fig. 2. Representatives of the Antarctic ornithofauna: northern giant petrels (Macronectes giganteus) in the Cooperation Sea, February 2007. Photo by N.N. Kukharev

Сегодня Антарктическая конвенция является одним из важнейших документов, разработанных в рамках Договора об Антарктике 1959 г., и входит в систему Договора об Антарктике вместе с Конвенцией о сохранении тюленей Антарктики (Лондон, 1972 г.), Протоколом об охране окружающей среды (Мадрид, 1991 г.) и многочисленными рекомендациями, принятыми на совещаниях Сторон Договора об Антарктике и вступившими в силу в соответствии с условиями договора. Согласно Конвенции ООН по морскому праву (1982 г.), Антарктическая конвенция трактуется как региональная организация по регулированию рыболовства, с дополнительно расширенными обязанностями по сохранению экосистемы Антарктики [14].

Комиссия по сохранению морских живых ресурсов Антарктики, АНТКОМ

В 1982 г. Антарктическая конвенция вступила в силу после ратификации пятнадцатью подписавшими ее государствами. В соответствии с положениями Конвенции эти государства создали особый орган управления - Комиссию по сохранению морских живых ресурсов Антарктики (Антарктическую комиссию, АНТКОМ) и ее структуры: Секретариат и, по инициативе СССР, Научный комитет, который дает научные рекомендации Комиссии.

В 1990-2000-е гг. к Антарктической конвенции присоединились Бразилия, Индия, Испания,
Италия, Китайская Народная Республика, Республика Корея, Намибия, Украина, Уругвай, Швеция, Европейский Союз. В настоящее время, с учетом объединения ГДР и ФРГ в единое государство, а также в связи с переходом прав СССР к Российской Федерации, участниками конвенции и членами комиссии являются 24 государства и Европейский союз, 15 из которых принимали участие в Конференции по сохранению морских живых ресурсов Антарктики, затем подписали и ратифицировали Антарктическую конвенцию. Делегации государств-членов постоянно участвуют в работе Комиссии и Научного комитета АНТКОМ, а также платят ежегодные взносы в бюджет АНТКОМ.

\section{Присоединившиеся страны}

Кроме государств, подписавших Антарктическую конвенцию, в деятельности, связанной с ее положениями, принимают участие присоединившиеся государства, заинтересованные в осуществлении исследовательской и/или промысловой деятельности в зоне действия Конвенции. Они не подписывали документ, но официально сообщили о своем согласии быть юридически связанными условиями данной Конвенции. В настоящее время к ней присоединилось 11 стран - Болгария, Вануату, Греция, Финляндия, Канада, Острова Кука, Маврикий, Нидерланды, Пакистан, Панама, Перу. В связи с тем, что Антарктическая комиссия работает в системе Договора об Антарктике, она приняла тот же механизм голосования, что и на Консультативных Совещаниях Договора об Антарктике. При рассмотрении «вопросов существа» (принятие регуляторных документов и т. п.) в процедуре принятия решений используется консенсусное голосование. По другим вопросам решения принимаются большинством голосов. Это существенно отличает АНТКОМ от других рыбохозяйственных организаций и комиссий - НАФО, НЕАФК и др., в которых все решения принимаются большинством голосов. Консенсусное голосование уравнивает в правах все страны-члены Комиссии и требует особо тщательной проработки «вопросов существа», которые в противном случае могут быть заблокированы любой страной-членом Комиссии. Страна, не заплатившая ежегодный взнос в АНТКОМ, лишается права голоса на весь год [14].

\section{О зоне ответственности АНТКОМ}

Площадь зоны ответственности АНТКОМ составляет около 36,3 млн кв. км (примерно $10 \%$ площади Мирового океана) и включает воды Южного океана 
между полярным фронтом и Антарктидой [18]. В соответствии с Конвенцией $\mathrm{OOH} \mathrm{по} \mathrm{морскому} \mathrm{праву}$ (1982 г.), акватория, находящаяся под управлением АНТКОМ, за исключением 200-мильных ИЭЗ (исключительных экономических зон) Франции у о. Кергелен, Австралии у о-вов Хёрд и Макдональд и так называемой «морской зоны» Великобритании у о-ва Южная Георгия, является открытыми водами Мирового океана. Большая часть морских живых ресурсов этой акватории распределяется в приматериковых морях Антарктиды, около $15 \%$ - в так называемой «морской зоне» о. Южная Георгия и в экономзонах у о. Кергелен и о-вов Хёрд и Макдональд. Государства, ответственные за ресурсы экономических зон, декларируют выполнение рекомендаций АНТКОМ по управлению.

Рабочие языки АНТКОМ - английский, испанский, русский, французский.

Членами Научного комитета являются все страны-члены АНТКОМ. К работе в Научном комитете привлекаются на контрактной основе известные специалисты в области рыбохозяйственных исследований. В течение года Научный комитет проводит заседания четырех постоянных рабочих групп по экосистемному мониторингу, оценке запасов, статистике и моделированию (связана с промыслом и побочной смертностью) и одной подгруппы по акустическим съемкам.

Каждая страна назначает ответственных специалистов для связей с АНТКОМ: официального представителя в Антарктической комиссии, в Научном комитете АНТКОМ и координатора по научному наблюдению.

Правовые вопросы существования и деятельности АНТКОМ. Правовой статус решений АНТКОМ

Конвенция АНТКОМ разрабатывалась в период подготовки Конвенции ООН по морскому праву, которая в свою очередь была разработана в 1982 г. и вступила в силу в 1994 г., став всеобъемлющим источником морского права для государств мира. В числе прочего, в ней были определены права государств по созданию международных региональных организаций по сохранению рыбных ресурсов и управлению ими в открытом море. Таким образом, созданная в 1982 г. Антарктическая комиссия утвердилась в правовом поле международного морского права в качестве региональной рыбохозяйственной организации, но с самостоятельно расширенными полномочиями по охране экосистемы Антарктики.
Решения АНТКОМ, как и любой другой международной организации, обязательны только для странчленов и не являются источником права для государств, не входящих в АНТКОМ. В настоящее время вся прилегающая к Антарктическому континенту акватория разделена на определенные участки. Схема данного районирования представлена на рис. 3 .

Противоречия Антарктической конвенции и Конвенции ООН по морскому праву

Антарктическая конвенция в Статье I, п. 2 отнесла к морским живым ресурсам всю биоту Антарктики, тогда как по общепринятому определению живыми ресурсами является только та часть биоты, которая необходима для существования человеческого общества и используется в хозяйстве. Конвенция ООН по морскому праву оперирует только этим понятием и не предусматривает создание и деятельность рыбохозяйственных организаций, регулирующих рыболовство в целях сохранения всей биоты.

\section{Система научного наблюдения АНТКОМ}

Все промыслы в водах Антарктики осуществляются только в рамках системы АНТКОМ по научному наблюдению, согласно которой на промысле клыкачей на каждом судне обязательно присутствие как минимум двух аккредитованных научных наблюдателей - международного (гражданин любой другой страны-участницы АНТКОМ) и национального (гражданин флага судна) либо двух международных наблюдателей.

Кроме того, страны-члены АНТКОМ пришли к соглашению о необходимости научного наблюдения на судах, ведущих промысел патагонского клыкача в водах Субантарктики, расположенных за пределами зоны АНТКОМ: в водах Юго-Западной Атлантики (Патагонский склон, банка Скоша) и ЮгоВосточной части Тихого океана, в ИЭЗ Чили. На промысле криля программа систематического охвата наблюдателями составляет следующую целевую норму: не менее $50 \%$ судов в течение промысловых сезонов 2016/2017 и 2017/2018 гг., не менее $75 \%$ - в течение промысловых сезонов $2018 / 2019$ и 2019/2020 гг. и 100 \% — в последующих промысловых сезонах. Общее количество наблюдателей на борту любого судна не ограничивается. Наблюдатель обязан владеть языком флага судна либо одним из рабочих языков АНТКОМ. Все научные наблюдатели проходят национальную или международную сертификацию и направляются на суда по решению государственных органов управ- 

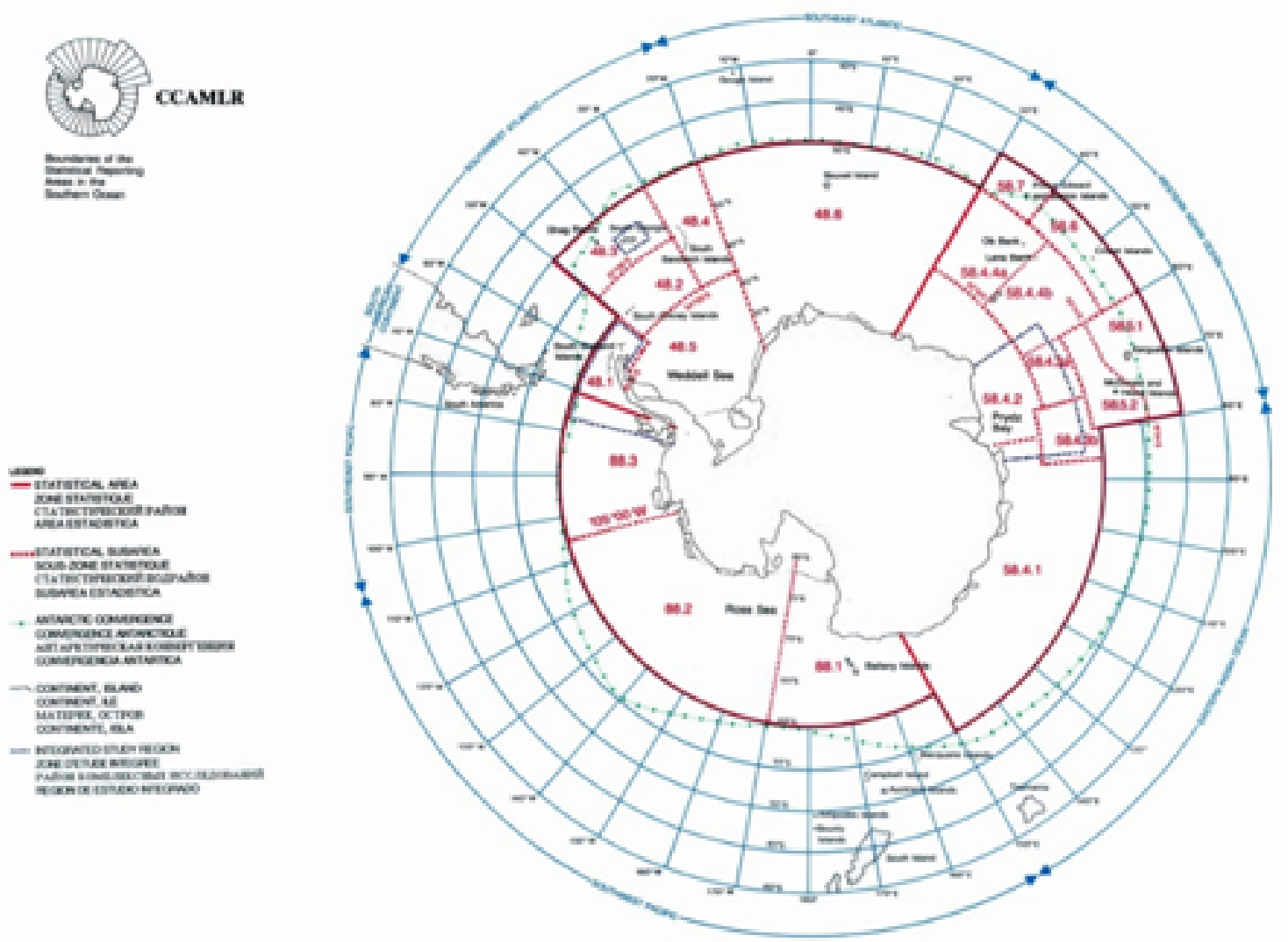

Рис. 3. Схема районирования АНТКОМ

Fig. 3. Chart of the CCAMLR zonation

ления рыболовством в соответствии с заявками, поданными судовладельцами. Деятельность и отчетность научных наблюдателей на борту промысловых судов подробно регламентированы документами АНТКОМ.

В обязанности научных наблюдателей входит сбор биологических данных, который включает в себя массовый промер и полный биологический анализ целевых объектов лова и организмов прилова (рис. $4,5,6$ ). Научные наблюдатели также участвуют в мечении рыб - объектов промысла и рыб прилова (рис. 7).

Важным элементом работы экипажа и научных наблюдателей является учет организмов-индикаторов уязвимых морских экосистем (УМЭ), поднятых на палубу крючковыми орудиями лова в ходе промысла клыкачей, поскольку в случае превышения установленных норм прилова этих организмов судно обязано сменить участок лова (рис. 8).

\section{Инспекционная система АНТКОМ}

Все страны-члены АНТКОМ имеют право проводить инспектирование любых промысловых судов стран-членов организации с использованием инспекционных судов и самолетов. В настоящее время проверку промыслов проводят инспекторы из Новой Зеландии и Австралии на инспекционных судах под флагами этих государств (рис. 9). Инспекторы проходят специальную подготовку и

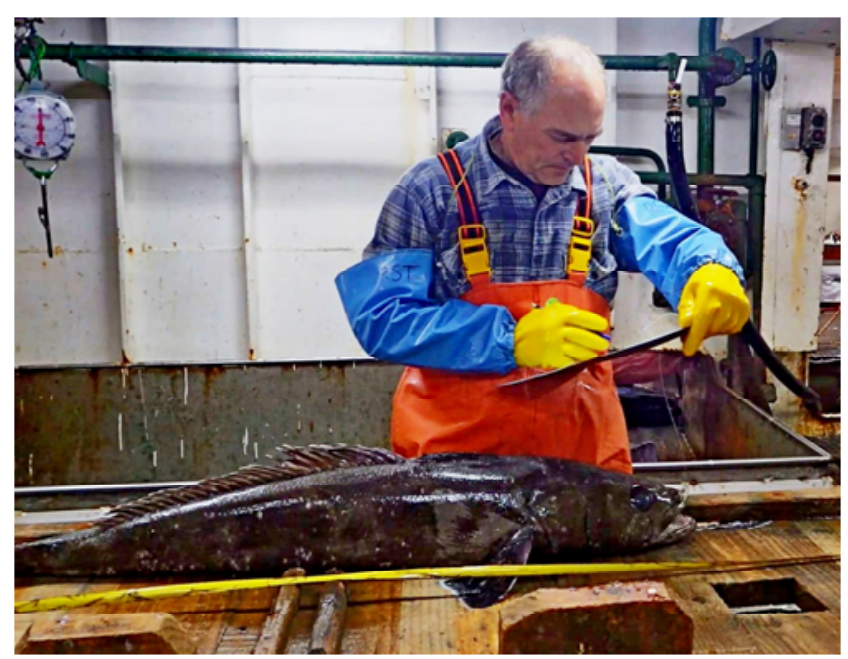

Рис. 4. Биологический анализ антарктического клыкача. Ярусолов «Kostar», Республика Корея. Mope Pocca, 21 декабря 2016 г. Фото С.Т. Ребика

Fig. 4. Biological analysis of the Antarctic toothfish. Longliner "Kostar", Republic of Korea. Ross Sea, 21 December 2016. Photo by S.T. Rebik 


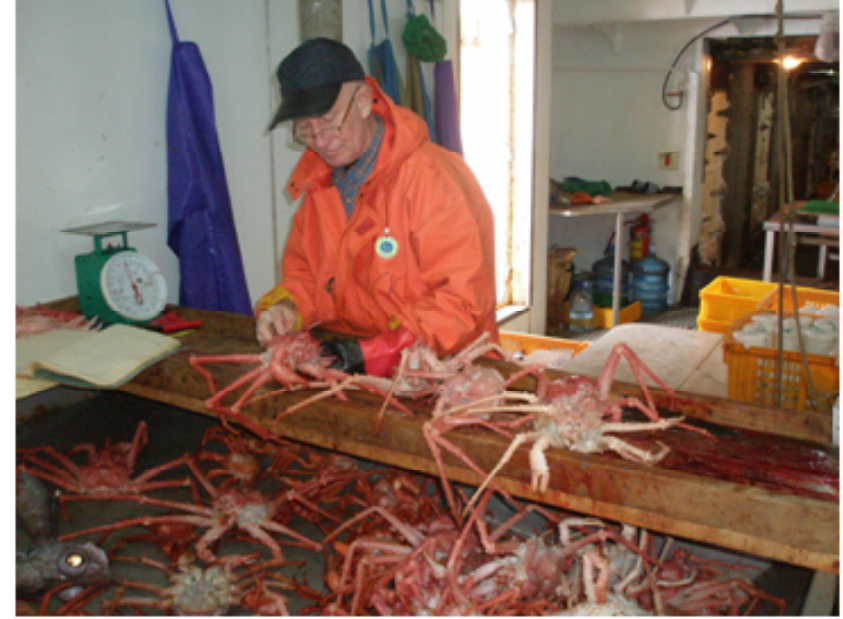

Рис. 5. Промер улова крабоидов Lithodes sp. Субантарктика, хребет Скоша. Ярусолов «Спарта», Россия. 9 марта 2010 г. Фото Н.Н. Кухарева

Fig. 5. Measuring the Lithodes sp. catches, Subantarctic area, the Scotia Ridge. Longliner "Sparta", Russia. 9 March 2010. Photo by N.N. Kukharev

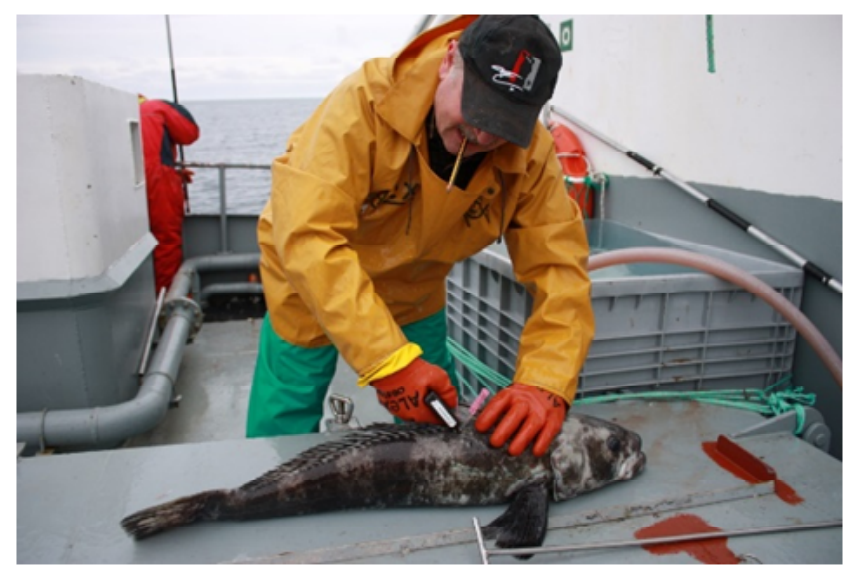

Рис. 7. Мечение антарктического клыкача Dissostichus mawsoni на борту испанского ярусолова «Tronio». Море Pocca, 2012 г. Фото А.К. Зайцева

Fig. 7. Tagging of the Antarctic toothfish Dissostichus mawsoni aboard the Spanish longliner "Tronio". Ross Sea, 2012. Photo by A.K. Zaytsev

действуют строго в рамках инспекционной схемы АНТКОМ, они также обязаны владеть языком флага проверяемого судна. По результатам инспекции проверяющий из АНТКОМ и капитан судна подписывают отчет о проведенной инспекции.

\section{Научный комитет}

На ежегодных совещаниях, которые проводятся непосредственно перед совещанием Комиссии, Научный комитет предоставляет Комиссии результаты своих исследований по вопросам управления промыслом, величинам вылова и их распределению

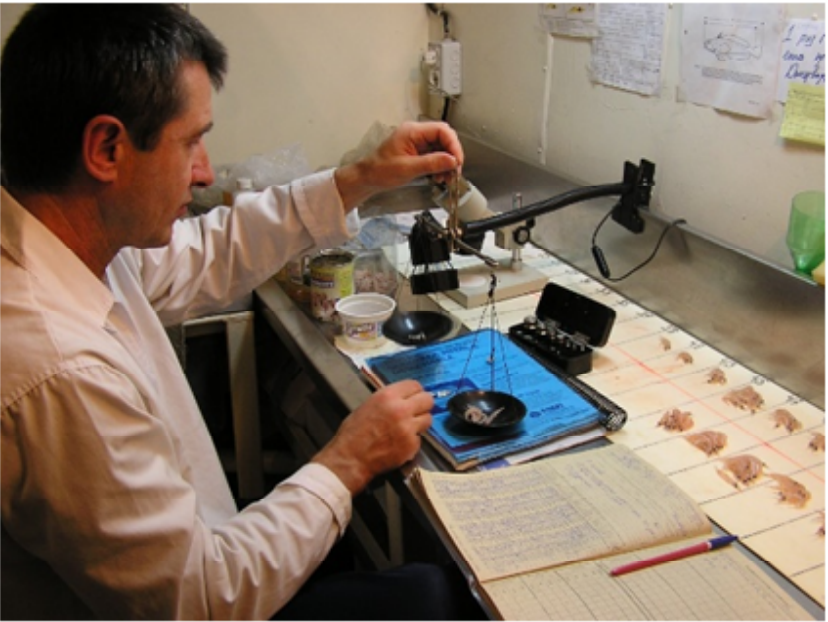

Рис. 6. Научный наблюдатель выполняет биологический анализ антарктического криля Euphausia superba на борту украинского РКТ-С «Конструктор Кошкин». Атлантическая часть Антарктики, подрайон 48.2, 2003 г. Фото Н.Н. Жука

Fig. 6. The scientific observer is performing a biological analysis of the Antarctic krill Euphausia superba aboard the Ukrainian krill fishing trawler "Konstructor Koshkin". Atlantic Antarctic, subarea 48.2, 2003. Photo by N.N. Zhuk

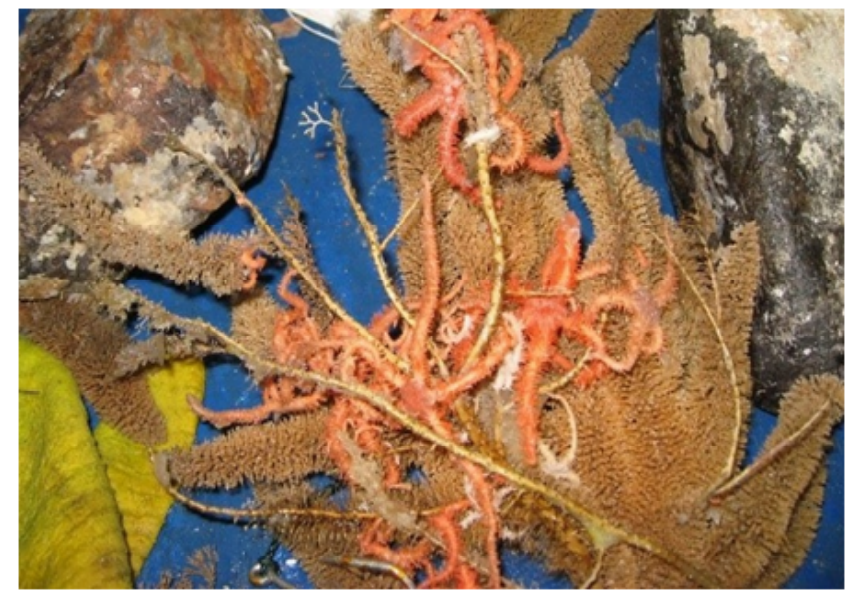

Рис. 8. Донные организмы-индикаторы (отряды Ophiurida и Gorgonacea) и камни, поднятые на палубу крючковыми орудиями лова в ходе промысла антарктического клыкача. Глубина лова 1200 м. Фото из архива лаборатории Мирового океана ФГБНУ «АзНИИРХ»

Fig. 8. Bottom organisms and stones captured by hook-bearing fishing gear during the Antarctic toothfish fishing. Fishing depth $1200 \mathrm{~m}$. Photo from the archives of the Laboratory of the World Ocean, FSBSI "AzNIIRKH”

по участкам лова, рекомендации по проведению исследований, Мерам по сохранению и пр. В соответствии с Конвенцией Антарктическая комиссия обязана полностью учитывать мнение и рекомен- 


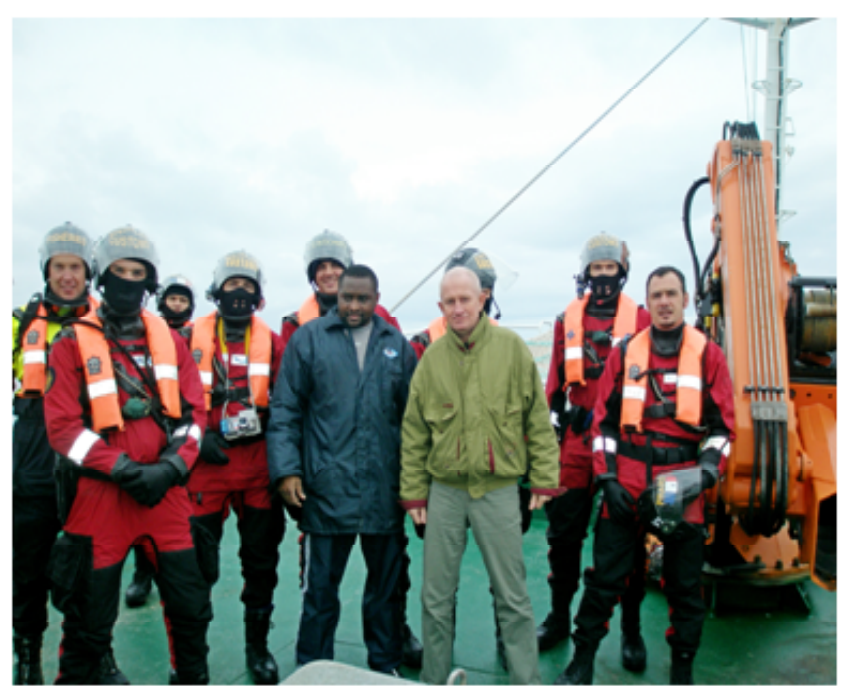

Рис. 9. Инспекционная проверка намибийского ярусолова «Antillas Reefer» инспекцией АНТКОМ совместно с таможенной службой Австралии с судна «Oceanic Viking». В центре - национальный и международный научные наблюдатели. Банка БАНЗАРЕ, Антарктическая часть Индийского океана, 14 марта 2007 г. Фото Н.Н. Кухарева

Fig. 9. Inspection of the Namibian longliner "Antillas Reefer" by CCAMLR inspection in conjunction with the Australian Customs from the inspection vessel "Oceanic Viking". National and international scientific observers (in the center). Underwater bank BANZARE, Southern Indian Ocean, 14 March 2007. Photo by N.N. Kukharev

дации Научного комитета при принятии своих решений.

Научный комитет собирает и обрабатывает информацию, полученную в ходе мониторинга промысла и собранную научными наблюдателями на промысловых судах, а также учитывает результаты деятельности программы по вопросам экосистемного мониторинга и морских отбросов. Важным источником информации для принятия решений являются результаты деятельности созданных Научным комитетом рабочих групп. На их ежегодных заседаниях делегации стран-членов АНТКОМ в ходе обширных дискуссий обсуждают важнейшие проблемы и предлагают рекомендации по вопросам промысла и сохранения экосистемы.

\section{Ежегодные совещания (сессии)}

АНТКОМ проводит ежегодные совещания (сессии) в г. Хобарт, Австралия в конце октября начале ноября. На Сессиях подводятся итоги деятельности Рабочих групп Научного комитета, которые проводились в разных странах в течение года, утверждаются списки судов, заявленных для промысла на текущий сезон. Делегациям государств предлагается рассмотреть и обсудить разработанные Научным комитетом специальные регуляторные документы АНТКОМ - Меры по сохранению (MC), определяющие объемы, сроки, способы лова для каждого объекта промысла, разрешенные орудия лова, периодичность и характер информации, которая должна поступать в секретариат Комиссии от научных наблюдателей и инспекторов, систему учета и выгрузки уловов, противодействие ННН-промыслу и т. п.

В голосовании участвуют только страны-члены АНТКОМ, у каждой из которых есть один голос. В ходе дискуссий при обсуждении предложений, представленных на совещаниях АНТКОМ, наибольшую активность проявляют делегации Австралии, России, Украины, Новой Зеландии, США, Великобритании, Японии, КНР. При этом обычно блоку Россия-Япония-КНР-Украина противостоят делегации Австралии, Великобритании, Новой Зеландии и США. В состав российских делегаций, участвующих в работе Совещаний, обычно входят представители Министерства иностранных дел, органов государственного управления, науки и промысла. На Совещаниях присутствуют представители КСДА, СКАР, КООС, ФАО, крупнейших мировых экологических и природоохранных организаций, сотрудничающих с АНТКОМ.

В настоящее время (сезон 2017/2018 гг.) действует шестьдесят девять МС, сгруппированные в разделы «Соблюдение», «Общие вопросы промысла», «Промысловые меры», «Охраняемые районы» и дополненные двадцатью одной Резолюцией по вопросам промысла, соблюдения и др.

Программа АНТКОМ по мониторингу экосистемы (СЕМР)

СЕМР была создана АНТКОМ в 1989 г. в соответствии с экосистемным подходом к управлению, указанным в статье II Антарктической конвенции. Программа предназначена для получения информации о воздействии промысла на целевые объекты лова, ассоциированные и зависимые виды. Цель программы - контроль за изменениями в морской экосистеме и выявление различий между изменениями, вызванными антропогенным воздействием (промыслом) и природными флуктуациями среды.

Усилия СЕМР сосредоточены в области мониторинга численности так называемых «зависимых» видов. Исследуя последствия промысла криля, программа в качестве «зависящих от криля видов» необоснованно использует наземные виды морских 
хищников - пингвинов и других птиц, а также тюленей, очевидно, вследствие их хорошей наблюдаемости, наименовав их «видами-индикаторами».

К таковым отнесены 4 вида пингвинов, 3 вида птиц и южный морской котик Arctocephalus gazella. По оценке Hinke et al. [19], несмотря на длительный срок работы СЕМР, параметризация функциональных реакций крилезависимых хищников на изменения биомассы и уловов криля остается сложной [7].

На основе всего периода деятельности СЕМР можно сделать вывод о том, что данная программа выявила значительные трудности в установлении признаков антропогенного воздействия на «видыиндикаторы» в связи с фактически непреодолимой сложностью задачи по разделению последствий промысла и массовых межгодовых колебаний запасов криля и численности «видов-индикаторов», по изменениям в методологии оценки их численности и пр.

Современные экспедиционные исследования в зоне АНТКОМ

В настоящее время наиболее стабильные наблюдения и академические исследования Антарктики проводятся в экспедициях на немецком исследовательском ледоколе «Polarstern» (рис. 10).

С 1982 г. это флагманское судно Института полярных и морских исследований им. Альфреда Вегенера (г. Бремерхафен, Германия) попеременно работает в Арктике и Антарктике, выполняя комп-

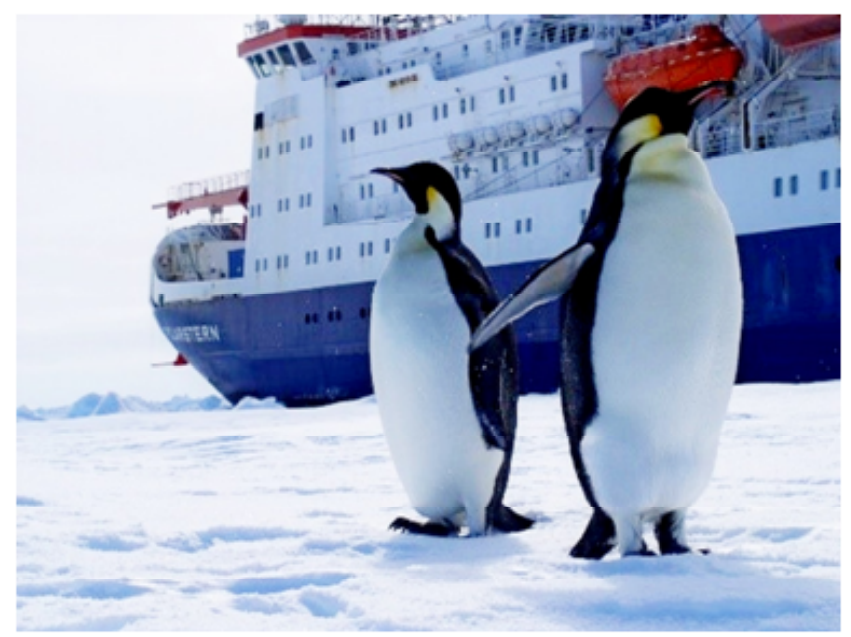

Рис. 10. Исследовательский ледокол «Polarstern» (Германия) и императорские пингвины. АЧА, 2006 г. Фото Л.К. Пшеничнова

Fig. 10. Research icebreaker "Polarstern" (Germany) and emperor penguins. Atlantic Antarctic, 2006. Photo by L.K. Pshenichnov лекс океанологических, гидробиологических и ихтиологических исследований, траловых работ, наблюдений за климатом и т. п. На борту обычно находятся до 57 ученых из разных стран. Участие бесплатное, попасть в экспедицию можно по рекомендациям ученых, ранее работавших на «Polarstern» (https://www.awi.de/en/expedition/ships/ polarstern.html). В экспедициях на НИС «Polarstern» периодически участвовали ученые России и Украины.

В 27-й антарктической экспедиции на НИС «Polarstern» (8.12 2010 - 2.022011 г.) работал сотрудник ВНИРО Д.О. Сологуб. В феврале 2017 г. НИС «Рolarstern» проводил исследования в море Амундсена (АЧТО, район 88), а в феврале 2018 г. в море Уэдделла (АЧА, район 48).

В 2000 г. в АЧА (район 48) была проведена последняя на данный момент международная тралово-акустическая съемка по программе АНТКОМ, в которой был выполнен учет запаса криля. В съемке участвовало российское научное судно НИС «Атлантида», принадлежащее ФГБНУ «АтлантНИРО». После 1991 г. это единственный случай проведения российской научно-исследовательской рыбохозяйственной экспедиции в Антарктику. Экспедиция оценила ОДУ криля в районе 48 на уровне около 4 млн т [20].

В 2007 г. Австралия выполнила тралово-акустическую съемку криля в АЧИО (район 58) в заливе Прюдс (море Содружества, подрайон 58.4.2). Общая биомасса криля в этом районе была оценена в 12,46 млн т, ОДУ — на уровне 1,2 млн т [20].

В июне 2017 г. начал свою деятельность Центр по исследованиям океанов Южного полушария (CSHOR), который представляет собой совместное предприятие Циндаоской национальной лаборатории морских наук и технологий (QNML) в г. Циндао (Китай) и Организации научных и промышленных исследований Содружества (CSIRO) (Австралия), которая является федеральным правительственным агентством по научным исследованиям в Австралии.

\section{Промысел и управление в зоне АНТКОМ}

С созданием Антарктической комиссии начался новый этап промысла в Антарктике. В середине 1980-х гг. в дополнение к существующим промыслам начался советский ярусный промысел патагонского клыкача в АЧА (о. Южная Георгия) и АЧИО (о. Кергелен), экспериментальный траловый промысел белокровки Вильсона Chaenodraco wilsoni, 
серебрянки Pleuragramma antarcticum, шипоносой белокровки Chionodraco rastrospinosus, электроны Карлсберга Electrona carlsbergi [6]. Антарктическая комиссия начала принимать Меры по сохранению (MC) в 1991 г., после ухода с антарктического промысла судов Минрыбхоза СССР и стран Восточной Европы [13]. После максимального вылова, достигнутого в Антарктике в 1982 г. (666 тыс. т), уже в 1993 г., с прекращением советского промысла, вылов в Антарктике упал до исторического минимума (73 тыс. т) [6].

В настоящее время промысел в зоне АНТКОМ ведется на основе разработанных Научным комитетом MC, в которых указаны величины допустимого улова для каждого объекта промысла, обычно с распределением по участкам лова. В промысле участвуют суда, заявленные страной-членом по установленной форме и утвержденные АНТКОМ. Заявки должны быть оплачены до начала промысла. На каждом судне обязательно присутствие научных наблюдателей, а также наличие лицензии (разрешения) на право ведения промысла в зоне АНТКОМ с указанием вида промысла; лицензия выдается государством флага. Промысловое усилие (количество судов на промысле) не ограничивается. Применяется олимпийский принцип в сочетании с ежесуточной промысловой отчетностью. Промысел проходит либо с даты его открытия до выбора квоты на данном участке, либо по достижении общего ограничения на вылов, либо до даты закрытия промысла (рис. 11, 12).

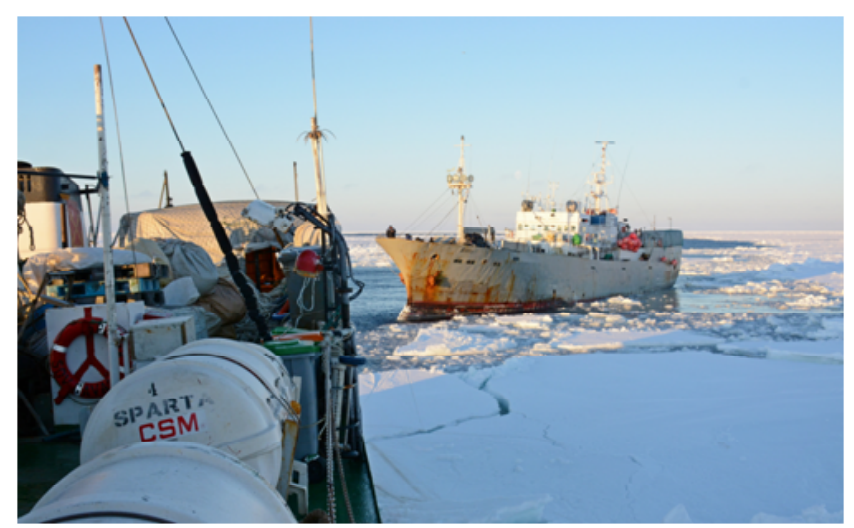

Рис. 11. Российские ярусоловы «Спарта»и «Угулан» проходят ледовые поля на промысле в море Росса. 11 декабря 2013 г. Фото Н.Н. Кухарева

Fig. 11. Russian longliners "Sparta" and "Ugulan" pass the ice fields during fishing operations in the Ross Sea. 11 December 2013. Photo by N.N. Kukharev

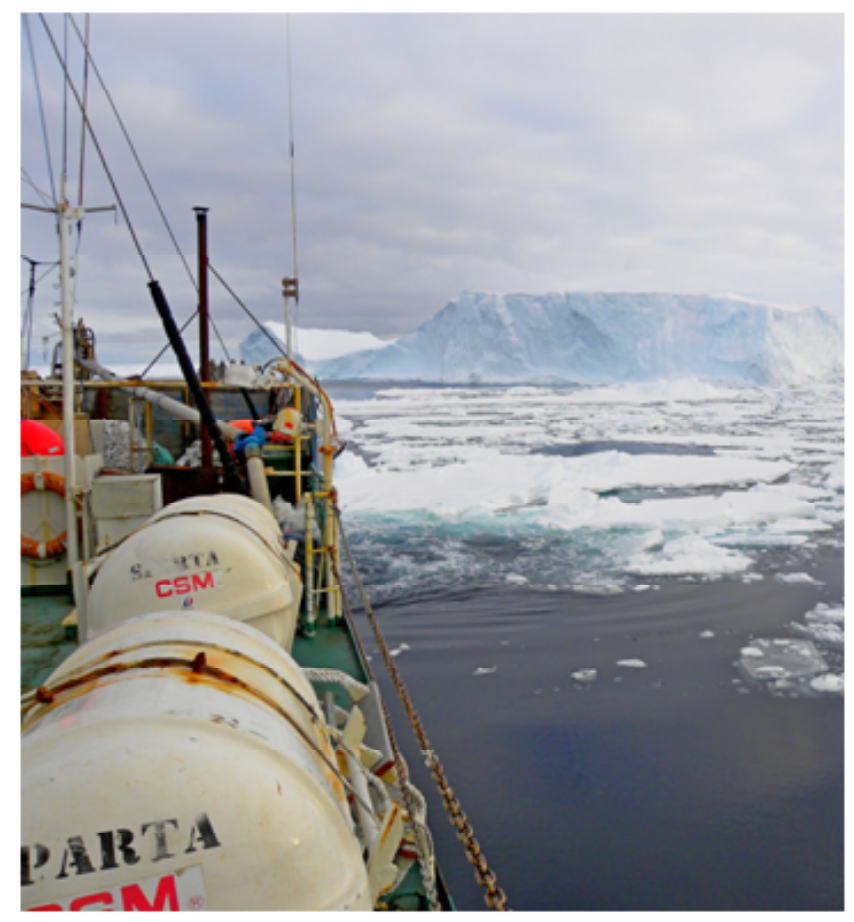

Рис. 12. Промысел антарктического клыкача в море Росса среди ледовых полей и айсбергов. Российский ярусолов «Спарта», декабрь 2013 г. Фото Н.Н. Кухарева

Fig. 12. The Antarctic toothfish fishing in the Ross Sea among ice fields and icebergs. Russian longliner "Sparta", December 2013. Photo by N.N. Kukharev

В последние годы (2007-2016 гг.) на долю криля приходится 92-94 \% общего вылова в Антарктике. В 2016 г., по данным ФАО, вылов, полученный в акватории под управлением АНТКОМ, составил 279 тыс. т, в т. ч. 260 тыс. т криля, 12 тыс. т патагонского (Dissostichus eleginoides) и 4 тыс. т антарктического (Dissostichus mawsoni) клыкача, 0,6 тыс. т ледяной рыбы (щуковидной белокровки Champsocephalus gunnari) и 2,4 тыс. т рыб прилова — макрурусов и антиморы [6]. Когда в 1991 г. в зоне АНТКОМ вместе с промыслом прекратились многочисленные советские исследовательские и поисковые экспедиции, страны-члены АНТКОМ в рамках предосторожного подхода закрыли промыслы нескольких видов нототений, ледяных рыб, электроны Карлсберга и антарктического клыкача в Индоокеанском и Атлантическом секторах Антарктики. При этом не было учтено, что текущая информация с промысла в сочетании с ретроспективными материалами могла бы стать источником данных для математического моделирования состояния запаса данных промысловых объектов. Теперь для открытия их промысла необходимы экспедиционные исследования современного состояния запасов. 
В 2016 г. промысел вели (по убывающей) Норвегия и КНР (криль), Республика Корея и Украина (криль, антарктический клыкач), Франция (патагонский клыкач), Чили (криль, патагонский клыкач), Австралия и Великобритания (патагонский клыкач, щуковидная белокровка, антарктический клыкач), Новая Зеландия и Российская Федерация (антарктический клыкач), Испания (антарктический клыкач), Уругвай (патагонский клыкач), ЮАР и Япония (антарктический и патагонский клыкачи). Из всех постсоветских республик только Российская Федерация и Украина продолжают вести промысел в зоне АНТКОМ до настоящего времени $[6,18]$.

Современный вылов антарктического и патагонского клыкачей регулируется на основе оценок запаса и допустимого улова, рассчитанных по возврату меток. В рамках предосторожного подхода учитываются риски, связанные с косвенными методиками учета. Промысел щуковидной белокровки регулируют на основе прямого учета запасов.

В настоящее время основным объектом промысла в зоне АНТКОМ является антарктический криль; на регулировании этого промысла сосредоточены управленческие усилия АНТКОМ. Вылов криля после максимума, достигнутого в 1982 г. (АЧА и АЧИО, 528 тыс. т), в 2010-2016 гг. сосредоточился в АЧА и находится на уровне 160-200 тыс. т, с тенденцией к росту. С 1990-х гг. и по настоящее время управление промыслом криля ведется на основе величин ОДУ, рассчитанных по результатам прямого учета, последний из которых был выполнен в 2000 г., а также при помощи моделирования на основе концепции предосторожного подхода $[2,11,21,22-25]$.

Основные тезисы, характеризующие современную ситуацию по регулированию промысла криля, можно найти в преамбуле МС 51-07 (2016). В ней намечены желаемые направления регулирования промысла криля, которые предстоит реализовать в недалеком будущем. Центральной частью МС является тезис, сформулированный в соответствии с концепцией предосторожного подхода, о необходимости распределения вылова криля в АЧА (статистический район ФАО - 48) таким образом, чтобы «...промысловая деятельность не оказала непреднамеренного и непропорционального воздействия на популяции хищников, особенно наземных хищников». В 2000 г. Э. Констебль и др. [22] охарактеризовал регуляторные усилия АНТКОМ в отношении промысла криля как предосторожный подход к управлению в связи со значительным количеством используемых при этом допущений и волевых решений. При этом существующая неопределенность связей и зависимостей в системе «вылов криля - последствия для консументов» при современном низком уровне промысла, отсутствие технических возможностей для их установления и отслеживания были понятны Научному комитету еще в начальный период регулирования [21].

В основе предосторожного подхода, применяемого АНТКОМ в отношении промысла криля, лежит искусственный элемент - субъективное предположение о вредности или безопасности того или иного действия, шага, уровня и пр. для экосистемы и ее основных элементов. По мнению В.П. Шунтова, переход к регулированию промысла на основе предосторожного подхода означает применение «субъективной интуитивной подгонки результатов без четких критериев осторожности и степени риска» [26].

С помощью моделирования АНТКОМ выработал опорные критерии предосторожности, каждый из которых - это «выведенная согласованным научным порядком расчетная величина, которая соответствует определенному состоянию ресурса и промысла. При этом предосторожный подход к управлению предполагает принятие превентивных усилий в условиях неопределенности информации рисков» [27]. Именно такие превентивные решения закреплены в МС, регулирующих современный промысел криля в АЧА, в т. ч. распределение порогового уровня вылова криля в АЧА (620 тыс. т) по подрайонам. При этом ОДУ криля в АЧА установлен АНТКОМ на уровне 5,3 млн т [28, 29].

На сайте АНТКОМ управленческие намерения этой организации представлены следующим образом: «Поскольку АНТКОМ отвечает за сохранение морских экосистем Антарктики, он применяет экосистемный подход к управлению» [27, 30]. Однако в связи с чрезвычайно большой сложностью реализации экосистемного подхода странычлены АНТКОМ согласились управлять ресурсами и промыслом на основе предосторожного подхода, который предполагает проведение превентивных мероприятий на основе предположений о вероятных негативных последствиях промысла для целевых, ассоциированных и зависимых видов [17]. 


\section{АНТКОМ и общественные природоохранные организации}

С середины 1980-х гг. во внешней и внутренней политике многих странах все большее влияние приобретают общественные природоохранные организации, такие как Гринпис, Всемирный фонд дикой природы, Международный союз охраны природы и природных ресурсов и т. д. Некоторые из их национальных отделений получили статус политических партий, активно влияющих на внешнюю и внутреннюю политику и экономику многих стран, в т. ч. участниц Договора об Антарктике [31]. Фактически к ним можно отнести и Договор об Антарктике 1959 г., который усилил свои природоохранные намерения путем разработки и принятия в Мадриде Протокола об охране окружающей среды к Договору об Антарктике (Мадридский протокол, 1991 г.). Деятельность АНТКОМ по сохранению экосистемы успешно сочетается с положениями Мадридского протокола, который определил Антарктику в качестве природного заповедника, предназначенного для мира и науки. При этом Мадридский протокол возложил усилия по охране среды на государства, являющиеся Сторонами Протокола, которые должны действовать в рамках национальных законодательств, тогда как подобная деятельность государств-членов АНТКОМ регламентирована принятыми сообща $\mathrm{MC}$, обязательными для исполнения вне зависимости от национальных законодательств [32].

АНТКОМ, как и другие международные организации по управлению рыболовством (НАФО, НЕАФК и др.), является межгосударственной общественной организацией, деятельность которой в значительной мере прозрачна и чьи результаты доступны мировому сообществу. В связи с тем, что в АНТКОМ входят все самые крупные и авторитетные государства мира, а деятельность этой организации связана с биотой и промыслом в Антарктике, планы и результаты работы АНТКОМ находятся в фокусе постоянного внимания средств массовой информации, в т. ч. принадлежащих природоохранным организациям, многие из которых носят практически экстремистский характер.

В настоящее время на официальной и неофициальной основе АНТКОМ взаимодействует с 20 межправительственными и неправительственными организациями и коалициями, среди которых ФАО, АСОК, АОА, Международный союз охраны природы и природных ресурсов (МОСП), Международ- ная китобойная комиссия (МКК), Межгосударственная океанографическая комиссия (МОК) и др., которые участвуют в обсуждениях на Сессиях АНТКОМ, но, в соответствии с Антарктической конвенцией, не имеют права голоса $[18,33]$.

По оценкам общественных природоохранных организаций, АНТКОМ, как и КООС, является одним из двух ключевых элементов системы Договора об Антарктике, которые ориентированы на сохранение ее сухопутных и морских экосистем. Многие из природоохранных организаций мира взаимодействуют или стремятся взаимодействовать с АНТКОМ в целях поднятия собственного авторитета.

Особенности современной политики управления АНТКОМ

В современной политике управления АНТКОМ проявляется все большая ориентация на пропагандируемые в СМИ и ничем не обоснованные, но наукообразно сформулированные природоохранные требования к мировому сообществу, включая предложения по полному запрету рыбного промысла в океане, по повсеместному введению МОР, по борьбе с последствиями изменений климата и пр., которые носят алармистский характер и рассчитаны на положительную оценку радикальной экологической общественности.

АНТКОМ не может игнорировать такие призывы и мнения, поскольку в них все более важную роль играет политическая составляющая. Начиная с 1991 г. и по настоящее время, на ежегодных совещаниях АНТКОМ делегации стран-членов получали от Научного комитета множество наукообразных аргументов о необходимости закрытия промыслов и соглашались с многими из них в надежде на то, что это носит временный характер. В этот период была закрыта большая часть промыслов. При этом можно не сомневаться, что в будущем хотя бы одно из государств региона, претендующее на акватории, примыкающие к его сектору, всегда будет против открытия закрытых промыслов, учитывая тот факт, что на сессиях АНТКОМ голосование происходит на основе консенсуса.

Некоторые ограничения, растиражированные в СМИ (запрет в зоне АНТКОМ на донные траления, ограничения взаимодействия донного яруса с организмами так называемых «уязвимых морских экосистем» - УМЭ), не имеют реальной научной основы и сформулированы под влиянием мнимых угроз для биоты. Примером такой мнимой угрозы 
является принятие странами-членами АНТКОМ Меры по сохранению 22-09 (2012) Охрана зарегистрированных уязвимых морских экосистем в подрайонах, участках, мелкомасштабных исследовательских единицах или районах управления, открьmых для донного промыслла, запрещающей донный траловый промысел и ограничивающей донный ярусный промысел на участках с повышенными концентрациями организмов УМЭ. Инициатором запрета выступила Австралия, которая в тот период в своей экономзоне (район островов Хёрд и Макдональд) вела глубоководный донный траловый промысел клыкачей с большим приловом донных организмов УМЭ [6]. Следует учесть, что в Антарктике для вылова нототений и ледяных рыб всегда использовались донные тралы.

Будучи растиражированными алармистскими природоохранными организациями, призывы к запрету донных тралений в океане неоднократно обсуждались в околонаучных мировых СМИ, а также рассматривались на сессиях Генеральной Ассамблеи ООН. Запрет на донные траления принят странами-членами в зоне АНТКОМ, однако при этом они не намерены применять этот запрет в водах под своей юрисдикцией. Например, Новая Зеландия при помощи донных тралений обеспечивает около 10 \%, Австралия - около $33 \%$, Канада - $43 \%$, Норвегия - 30 \% национального вылова [6]. Указанные страны, как и многие другие, десятилетиями используют в своих водах донные тралы и яруса для добычи донных и придонных гидробионтов.

Негативные последствия донных тралений сильно преувеличены алармистскими экологическими организациями. Например, губки, составляющие основу глубоководных донных биоценозов в Антарктике, имеют мощный механизм регенерации и наиболее устойчивы к внешнему воздействию. По своей способности к регенерации губки превосходят все многоклеточные организмы, хотя среди губок разных видов выявлены существенные различия в скорости восстановления [34-36]. Более того, донный ярус признан щадящим, наименее воздействующим на дно орудием лова [37].

В связи с высокой долей политической составляющей в деятельности АНТКОМ при голосовании по общественно значимым вопросам, в делегации Российской Федерации решения принимает МИД [38]. Аналогичная схема принята и у ряда других государств-членов.
Важной особенностью регуляторной политики АНТКОМ являются закрепленные в Статье II п. 3 Антарктической конвенции положения о применении принципов сохранения только в ходе промысла и связанной с ним деятельности. При этом Конвенция не содержит каких-либо положений и упоминаний о деятельности по сохранению морских живых ресурсов вне промысла и вне связи с промыслом. Однако в последние годы государствачлены АНТКОМ сочли возможным отступить от этих регуляторных принципов и расширить деятельность организации по сохранению экосистемы Антарктики вне связи с промыслом.

\section{АНТКОМ и морские охраняемые районы (МОР)}

Поворот в управленческой деятельности Антарктической комиссии, фактически выходящей за пределы Антарктической конвенции, начался в 2005 г., когда Секретариат и Научный комитет АНТКОМ, реализуя рекомендации Всемирной встречи в Йоханнесбурге в 2002 г., стали прилагать значительные усилия по созданию сети МОР в Антарктике. При этом никаких оснований для беспокойства стран-членов не было: уровень общего вылова в зоне АНТКОМ оставался крайне низким по сравнению с запасами промысловых объектов и с выловом в 1980-е гг. (около 670 тыс. т). В 2005 г. общий вылов в Антарктике составил 148 тыс. т, из них 129 тыс. т (87 \%) составил криль, остальное щуковидная белокровка, патагонский и антарктический клыкачи [6].

В 2005 г. на межсессионном совещании Научного комитета АНТКОМ был принят документ, представленный делегациями Австралии, Франции и Европейского Союза, «Научные предпосылки предлагаемой Восточно-Антарктической репрезентативной системы морских охраняемых районов» [39]. Следуя рекомендациям Всемирной встречи в Йоханнесбурге, многие прибрежные государства создают, исследуют и охраняют МОР в собственных экономзонах, но в открытых водах создание MOP под управлением какого-либо государства невозможно, поскольку это противоречит Конвенции ООН по морскому праву. Вопреки этому, в 2007 г. государства КСДА призвали страны-члены АНТКОМ к созданию сети МОР в открытых водах Антарктики.

В 2009 г. Секретариат начал настойчиво предлагать странам-членам создать МОР в Антарктике с условием передачи этих акваторий под управление ряду стран-членов АНТКОМ. В 2009 г. страны- 
члены АНТКОМ приняли МС 91-03 (2009) Охрана южного шельфа Южных Оркнейских островов, учредив в секторе территориальных притязаний Великобритании МОР площадью около 46 тыс. кв. км, с глубинами более 1000-3000 м, в целях сохранения морского биоразнообразия. Отчет об исследованиях в этом МОР так и не был представлен.

В 2011 г., на XXX сессии АНТКОМ, государствачлены приняли МС 91-04 (2011) Общая система для создания морских охраняемых районов АНТКОМ. Инициатором создания данной системы явился радикальный «Альянс Антарктического океана», неправительственная организация, которая предложила создать сеть МОР и закрытых для промысла морских заповедников в 19 конкретных районах вокруг Антарктиды.

В течение 2011-2015 гг. секретариат АНТКОМ с подачи Научного комитета оказывал постоянное давление на делегации стран-членов, пытаясь склонить их к голосованию за принятие обширных МОР площадью в несколько млн кв. км, прилегающих к секторам территориальных притязаний Австралии, Новой Зеландии, Франции и пр. и выходящих за пределы зоны АНТКОМ, с передачей их под управление указанных государств. Россия, Украина, а затем КНР и Япония, блокируя этот вопрос при голосовании, выступили против передачи акваторий открытых вод Мирового океана под управление какого-либо государства, заявив, что это противоречит Конвенции ООН по морскому праву и что у Антарктической конвенции недостаточно полномочий для такой деятельности, а также потребовали научно обосновать создание МОР в конкретной акватории.

После провала внеочередной сессии АНТКОМ в г. Бремерхафен (Германия, июль 2013 г.), посвященной созданию МОР, когда РФ, Украина, КНР и Япония заблокировали этот вопрос, особенно отчетливо проявились устремления некоторых государств региона к немедленному созданию МОР в зоне АНТКОМ без всяких многосторонних дискуссий и предложений, не совпадающих с таковыми Секретариата. Их можно оценить в приветственном слове губернатора Тасмании Питера Андервуда на открытии XXXII Сессии АНТКОМ (2014 г.): «...Вне всякого сомнения, результаты ваших дискуссий в Бремерхафене были восприняты неоднозначно. В мире существует открыто выражающее свое мнение и политически активное сообщество, которое раздражают обстоятельные многосторон- ние процессы, действующие при рассмотрении этих предложений о МОР. Это сообщество надеется, что АНТКОМ успешно добавит новые МОР к объявленному в 2009 г. МОР Южных Оркнейских о-вов и тем самым продемонстрирует наличие значительного прогресса в деле создания репрезентативной системы МОР в зоне действия конвенции АНТКОМ...» $[18,39]$.

Необходимо особо отметить, что сегодня деятельность АНТКОМ по организации МОР в Антарктике и сопутствующая ей дискуссия сопровождается обширной и беспрецедентной информационной кампанией в интернет-пространстве, направленной на поддержку создания МОР в Антарктике. Эта кампания имеет в основном антироссийскую направленность и развернута такими алармистскими организациями, как Антарктический Альянс, Международный союз охраны природы и природных ресурсов (МСОП) и пр. Отвергая любые доводы, сторонники МОР голословно обвиняли протестную деятельность делегаций России и Украины, а позднее - КНР и Японии как противоречащую самим идеям сохранения жизни в Антарктике. Не вдаваясь в суть дискуссии, они требовали немедленного введения МОР в «последнем не затронутом человеком регионе планеты» - море Росса. МОР объявлен единственной основой спасения жизни в этом море и в целом в Антарктике. Иных обоснований для создания МОР в этом море не предъявлялось [40-42].

Море Росса сложно отнести к категории «последнего не затронутого человеком региона планеты». Это море входит в сектор территориальных притязаний Новой Зеландии и с момента его открытия в 1841 г. довольно интенсивно использовалось человеком. В 1956 г. на южном берегу моря Росса основана полярная станция Мак-Мердо (США), в 1957 г. — «Скотт» (Новая Зеландия), затем совместная научная станция «Халлетт» (Италия и Республика Корея), строится станция КНР. В 1970-е гг. советскими экспедициями в море Росса были разведаны запасы криля и осуществлялся его промысел. До второй половины 1980-х гг. в этом районе новозеландцы охотились на тюленей для прокорма ездовых собак на станции «Скотт». Сегодня это основной район международного промысла антарктического клыкача, который ведется с 1998 г. по настоящее время, с ежегодным выловом около 3-4 тыс. т. На промысле работает до 1618 судов разных стран. Полярные станции, распо- 
ложенные на берегах моря Росса, вопреки требованиям МОР снабжались и будут снабжаться морским путем при помощи танкеров и контейнеровозов в сопровождении ледоколов. На дне моря вблизи станции Мак-Мердо обнаружены залежи отслужившей техники и оборудования: для их захоронения использовалось уникальное явление - весенний дрейф зимнего льда на север, формирующий знаменитую полынью моря Росса. Старое оборудование помещали зимой на лед, а весной его выносило в открытое море [43].

Существуют и проблемы радиационного загрязнения от запущенной в 1962 г. атомной станции на базе Мак-Мердо. После утечки радиации в 1973 г. она была эвакуирована, в течение семи лет оттуда вывозили оборудование и 9 тыс. м $^{3}$ зараженного грунта $[44,45]$. Нет ясности и с захоронением ядерных отходов, которые в 1960-е гг. было принято затапливать на глубоководье.

Таким образом, море Росса невозможно считать незатронутым уголком планеты с неизведанной биотой. Напротив, существует много доказательств того, что это море относится к наиболее изучаемым в Антарктике. В своей недавней работе, характеризующей динамику растворенного органического углерода в море Росса, Сара Беркович и др. [46] приводит более 40 работ, посвященных только продукционным процессам в этом море. Неизвестны и угрозы экосистеме моря Росса, требующие организации заповедника. Очевидно, реальной причиной создания МОР в море Росса было желание Новой Зеландии получить его под собственное управление, поскольку эта страна всегда считала акваторию моря Росса своим внутренним морем.

В июне 2016 г. в Москве прошла неофициальная встреча представителей 23 стран-членов АНТКОМ, на которой не удалось убедить РФ создать МОР в море Росса под управлением какого-либо государства. После неудач с передачей акваторий МОР под управление определенного государства Секретариат, в соответствии с рекомендациями ФАО, предложил создать МОР под управлением АНТКОМ. По оценкам МИД РФ, «...в итоговом решении 35-го совещания АНТКОМ ... был найден устраивающий все стороны баланс базовых интересов охраны окружающей среды и устойчивого использования морских биоресурсов Антарктики на основе наилучших имеющихся научных данных» [38]. Этот баланс был достигнут тем, что в создаваемом МОР была выделена акватория для промысла антаркти- ческого клыкача, а предохранительное ограничение на вылов клыкача в условиях МОР в сезон 2017/2018 гг. оставлено в том же объеме, который был установлен в сезон 2012/2013 гг. - 3157 т.

Таким образом, в октябре 2016 г. на XXXV Сессии АНТКОМ государства-члены АНТКОМ единогласно приняли МС 95-01 (2016) Морской охраняемый район в регионе моря Росса, невзирая на то, что Научный комитет не предоставил никакого научного обоснования для создания данного МОР под управлением АНТКОМ. Так называемый «МОР в море Росса», с общей площадью 1,55 млн кв. км (452 тыс. кв. миль), является крупнейшей по площади природоохранной зоной в мире и не будет находиться под управлением какого-либо государства. Предполагается, что регулирование антропогенной деятельности на акватории МОР в море Росса будет осуществляться совместными усилиями государств-членов АНТКОМ.

При этом созданный вариант МОР во многом является лишь условным понятием. АНТКОМ признает, что «...термин (МОР) не имеет единого определения, но в общих чертах МОР представляет собой морской район, обеспечивающий охрану всех или части находящихся в нем природных ресурсов». Вместе с тем Антарктическая конвенция не предусматривает для государств, ее подписавших, какую-либо возможность охраны акватории, в которой она действует, а наличие такого «района» не остановит ни транспортные суда полярных станций, ни достаточно многочисленные туристические суда, ни рыбаков тех государств, которые не присоединились к Антарктической конвенции.

Все вышеизложенное позволяет утверждать, что МОР под управлением АНТКОМ - условность, которую фактически соблюдают только участники Конвенции. Виды и направления деятельности в нем определены МС 91-04 (2011) и носят в основном декларативный характер. Основу составляют предложения по охране ареалов, районов, экологических сообществ, по сохранению биоразнообразия и т. п., при этом отсутствует упоминание как об угрозах, так и о данных о состоянии изученности биоразнообразия и пр.

С созданием MOP в море Росса и с учетом закрытых ранее акваторий на данный момент стали недоступными около 70 \% промысловых участков Антарктики. Тем временем Секретариат АНТКОМ, вдохновленный появлением МОР в море Росса, продвигает вопросы организации сети МOP 
в море Уэдделла, учитывая позицию РФ [40]. Планы создания этих МОР интенсивно обсуждаются на рабочих группах АНТКОМ; наибольшими сторонниками создания МОР в Антарктике выступают представители Великобритании, Германии, США, Австралии, Новой Зеландии, ЕС и др. [47].

Следует отметить, что Конвенция ООН по морскому праву не наделяет государства и международные организации правами по отторжению акваторий в открытых водах Мирового океана от промыслового использования с передачей их под управление какого-либо государства. Антарктическая Конвенция не предусматривает какой-либо деятельности по охране и защите акваторий и биоты, в т. ч. путем создания МОР, в связи с тем, что зоной действия Конвенции являются открытые воды Мирового океана, в которых деятельность государств регламентирована Конвенцией $\mathrm{OOH}$ по морскому праву. Таким образом, государства-члены АНТКОМ, объявив МОР в открытых водах Антарктики и намереваясь какимто образом его охранять, тем самым вышли за правовые пределы Антарктической конвенции и Конвенции $\mathrm{OOH}$ по морскому праву.

Деятельность АНТКОМ по ограничению промысла в Антарктике вступает в противоречие с огромной значимостью региона для человечества как источника пищевого и технического сырья. В соответствии с результатами интенсивных 30-летних советских и зарубежных рыбохозяйственных исследований, зона Антарктики под управлением АНТКОМ представляет собой крупнейший на планете недоиспользуемый промысловый ресурс, включая запасы криля, 70-75 \% которых приходится на АЧА. Возможный вылов криля в АЧА и АЧИО определен АНТКОМ на уровне 8,6 млн т/год, возможный вылов рыбы, включая нототений, ледяных рыб, миктофид (электрона Карлсберга Electrona carlsbergi), антарктическую серебрянку Pleuragramma antarcticum, — около 1 млн т/год [6].

\section{ЗАКЛЮЧЕНИЕ}

Интенсивное развитие крилевого и рыбного промысла в Антарктике в конце 1970-х гг. вызвало обеспокоенность государств КСДА и привело к разработке ими Конвенции о сохранении морских живых ресурсов Антарктики и созданию Антарктической комиссии (АНТКОМ), которая приступила к работе в 1982 г. Конвенция декларировала применение экосистемного подхода к управлению промыслом и сохранению живых ресурсов, к кото- рым была отнесена вся биота Антарктики, включая птиц (исключение - китообразные) [48]. Однако приступив к работе, Комиссия, ввиду отсутствия с 1991 г. мониторинга состояния ресурсов, вынужденно перешла к управлению промыслом на основе предосторожного подхода, основанного на моделировании и значительном количестве используемых допущений и волевых решений. В связи с доминированием промысла криля (более $90 \%$ вылова в Антарктике), Комиссия сосредоточила усилия на управлении его промыслом и защите птиц и тюленей, потребителей криля, от вероятных последствий воздействия промысла на его запас.

С 2005 г. некоторые государства-члены АНТКОМ предпринимают существенные усилия для изменения регуляторной политики Комиссии и смещения акцентов ее управленческой деятельности. Эти государства, под предлогом соблюдения рекомендаций Всемирной встречи в Йоханнесбурге в 2002 г. по созданию сети МОР в открытых водах Мирового океана и при поддержке радикальных общественных экологических организаций, намеревались получить от остальных государств-членов АНТКОМ одобрение на право создания МОР на огромных акваториях открытых вод Мирового океана, примыкающих к секторам их территориальных притязаний на Антарктическом континенте, и на право управления ими. Под давлением этих государств Антарктическая комиссия сместила свои управленческие усилия от вопросов регулирования рыболовства в сторону неприкрытых попыток раздела акватории открытых вод Мирового океана, примыкающих к Антарктиде, путем передачи их под управление государств региона под предлогом защиты уникальной антарктической биоты. В частности, предполагалось создание МОР под управлением Новой Зеландии в районе моря Росса, где ведется промысел антарктического клыкача, и в прилегающей акватории, включая участок Антарктического циркумполярного течения. Россия, Украина и ряд других государств блокировали создание этого МОР в связи с отсутствием научных обоснований, а передача акваторий открытых вод Мирового океана под управление какого-либо государства не предусмотрена Конвенцией ООН по морскому праву. Компромисс был достигнут путем создания МОР под управлением АНТКОМ и выделения участка для промысла с выловом на уровне прошлых лет. 
С учетом достигнутого компромисса АНТКОМ развивает идеи создания сети МОР вокруг Антарктического континента с возможностью промысла в них. Изменение регуляторной политики АНТКОМ в сторону создания сети МОР в Антарктике во многом ориентировано на положительную реакцию международных неправительственных природоохранных организаций и заинтересованной мировой общественности. МОР, по некоторым оценкам, представляют собой один из наиболее эффективных управленческих ответов на воздействие человека. Возможно, в районах с минимальным воздействием человека они могут служить критерием эффективности управления и выступать в качестве последних убежищ для наиболее уязвимых видов, однако их способность поддерживать разнообразие видов, функциональные роли и биомассу рыб остается сомнительной, в частности в регионах с глубоким и длительным антропогенным воздействием, тем более в условиях таких интенсивных гидрологических процессов, как Антарктическое циркумполярное течение [49].

Не приходится сомневаться, что в случае реализации планов некоторых стран-членов АНТКОМ по закрытию большей части акватории Антарктики подобными МОР уловы в них придется сводить к минимуму и какое-либо развитие рыболовства в Антарктике станет невозможным, а огромные биоресурсы этого региона станут недоступными для человечества. В таком случае само существование Антарктической Комиссии как организации, регулирующей рыболовство, во многом потеряет смысл. Можно предположить, что именно к этому стремятся государства-члены АНТКОМ, имеющие территориальные притязания в Антарктике при поддержке радикальных экологических общественных организаций.

\section{СПИСОК ЛИТЕРАТУРЫ}

1. Aronson R.B., Thatje S., McClintock J.B., Hughes K.A. Anthropogenic impacts on marine ecosystems in Antarctica // Annals of the New York Academy of Sciences. 2011. No 1223 (1). 82 p. doi: 10.1111/j.17496632.2010.05926.x.

2. Bridging the krill divide: Understanding cross-sector objectives for krill fishing and conservation. Report of an ICED-BAS-WWF workshop on understanding the objectives for krill fishing and conservation in the Scotia Sea and Antarctic Peninsula Region, held at WWF's Living Planet Centre, Woking, UK on $9^{\text {th }} \& 10^{\text {th }}$ June 2014. S. Hill, R. Cavanagh, C. Knowland, S. Grant,
R. Downie. (Eds.). Cambridge: NERC Publ., 2014. 38 p. URL: https://www.iced.ac.uk/documents/Krill\% 20divide\%20report_FINAL.pdf (дата обращения 29.07.2018).

3. Convey P., di Prisco G., Gutt E., Hodgson D., Mayewski P., Summerhayes C. Antarctic climate change and the environment // Antarctic Science. 2009. Vol. 21, issue 6. Pp. 541-563. doi: 10.1017/ S0954102009990642.

4. Tin T., Fleming Z., Hughes K., Ainley D., Convey P., Moreno C., Snape I. Impacts of local human activities on the Antarctic environment // Antarctic Science. 2009. No 21 (1). Pp. 3-33. doi: 10.1017/S0954102009001722.

5. Trathan P., Hill S., Belchier M., Grant S. Krill fishing and conservation in the Southern Ocean // British Antarctic Survey. 2018. URL: https://www.bas.ac.uk/ data/our-data/publication/krill-fishing-and-conservationin-the-southern-ocean/ (дата обращения 24.07.2018).

6. Fisheries and aquaculture software. FishStatJ - software for fishery statistical time series. URL: $h t t p: / /$ www.fao.org/fishery/statistics/software/fishstatj/en (дата обращения 23.07.2018).

7. Промысел и стабильность запасов криля // Промыслы CCAMLR. 2018. URL: https://www.ccamlr.org/ru/ fisheries/промысел-и-стабильность-запасов-криля (дата обращения 06.07.2018).

8. Бизиков В.А. Итоги XXXII совещания АНТКОМ: почему страны не могут договориться о создании морских охраняемых районов в Антарктике? // Международное сотрудничество ВНИРО. 2013. URL: http://www.vniro.ru/ru/novosti/novosti-2013/itogi-xxxiisoveshchaniya-antkom-pochemu-strany-ne-mogutdogovoritsya-o-sozdanii-morskikh-okhranyaemykhrajonov-v-antarktike (дата обращения 18.07.2018).

9. Колесникова Е.А. Антарктика: история освоения и перспективы // Вестник Московского университета. 2015. № 4. C. 182-203. URL: http://fmp.msu.ru/ attachments/article/361/KOLESNIKOVA_2015_4.pdf (дата обращения 21.07.2018).

10. Шуст К.В. О международной деятельности ВНИРО и бассейновых рыбохозяйственных институтов в сфере рационального использования морских живых ресурсов Антарктики // Труды ВНИРО. 2005. Т. 145. C. 113-122.

11. Atkinson A., Fielding S., Schmidt K., Venables H., Enderlein P., Schlosser C., Achterberg E., Patey M. The role of krill in Southern Ocean nutrient cycles: fieldwork report (Season 2010/2011) // British Antarctic Survey. JCR Cruise. JR245/JR246/JR247: Western Core Box, the role of krill grazing in Southern Ocean nutrient cycles, and AFI-CGS Individual physiological and behavioral responses of krill to distributional shifts and thermal change. Cambridge: NERC Publ., 2011. Pp. 5972. URL: https://www.bodc.ac.uk/resources/inventories/ cruise_inventory/reports/jr245.pdf (дата обращения 06.07.2018). 
12. Шуст К.В., Бизиков В.А. Роль СССР и России в формировании международного правового режима сохранения и рационального использования морских биоресурсов Антарктики // Труды ВНИРО. 2010. T. 149. C. $438-451$.

13. Шуст К.В., Бизиков В.А. Изучение и промысловое освоение биологических ресурсов Антарктических вод // Вопросы рыболовства. 2010. Т. 11. № 4 (44). С. 765-779.

14. Корзун В.А. Оценка возможностей использования ресурсов Антарктики. М.: Изд-во ИМЭМО РАН, 2009. 116 c. URL: https://docplayer.ru/27328238-V-akorzun-ocenka-vozmozhnostey-ispolzovaniya-resursovantarktiki.html (дата обращения 06.07.2018).

15. Final Act of the Conference for the Conservation of Antarctic Marine Living Resources, Canberra, Australia, 7-20 May, 1980. URL: https://www.ccamlr.org/en/ system/files/Conference $\% 20$ on $\% 20$ the $\% 20$ Conservation $\% 20$ of $\% 20$ Antarctic $\% 20$ Marine $\% 20$ Living\%20Resources.pdf (дата обращения 24.07.2018).

16. Самышев Э.3. Антарктический криль и структура сообщества в его ареале. М.: Наука, 1991. 168 с.

17. Constable A.J. The ecosystem approach to managing fisheries: achieving conservation objectives for predators of fished species // CCAMLR Science. 2001. Vol. 8. Pp. 37-64.

18. Об АНТКОМ. Сохранение морской жизни в Антарктике. URL: https://www.ccamlr.org/ru/organisation/обантком (дата обращения 12.07.2018).

19. Hinke J.T., Cossio A.M., Goebel M.E., Reiss C.S., Trivelpiece W.Z., Watters G.M. Identifying risk: Concurrent overlap of the Antarctic krill fishery with krilldependent predators in the Scotia Sea // PLOS ONE. 2017. No 12 (1). doi: 10.1371/journal.pone.0170132.

20. Atkinson A., Nicol S., Kawaguchi S., Pakhomov E., Quetin L., Ross R., Hill S., Reiss C., Siegel V. Fitting Euphausia superba into Southern Ocean food-web models: a review of data sources and their limitations // CCAMLR Science. 2012. Vol. 19. Pp. 219-245. URL: https://www.ccamlr.org/en/system/files/ science_journal_papers/Atkinson-krill.pdf (дата обращения 30.07.2018).

21. Constable A.J. Lessons from CCAMLR on the implementation of the ecosystem approach to managing fisheries // Fish and Fisheries. 2011. Vol. 12, issue 2. Pp. 138-151. doi: abs/10.1111/j.1467-2979.2011. 00410.x.

22. Constable A.J., de la Mare W.K., Agnew D.J., Everson I., Miller D. Managing fisheries to conserve the Antarctic marine ecosystem: practical implementation of the Convention on the Conservation of Antarctic Marine Living Resources (CCAMLR) // ICES Journal of Marine Science. 2000. No 57. Pp. 778-791.

23. Garcia S.M., Rosenberg A.A. Food security and marine capture fisheries: characteristics, trends, drivers and future perspectives // Philosophical Transactions of the Royal Society. Biological Sciences. 2010. No 365. Pp. 2869-2880. doi: 10.1098/rstb.2010.0171.

24. Gascón V., Werner R. CCAMLR and Antarctic krill: Ecosystem management around the great white continent // Ocean \& Fisheries Law. 2006. Vol. 7, issue 1. Pp. 1416. URL: http://digitalcommons.wcl.american.edu/cgi/ viewcontent.cgi?article $=1198 \&$ context $=$ sdlp (дата обращения 24.07.2018).

25. Hill S.L., Murphy E.J., Reid K., Trathan P.N., Constable A.J. Modelling Southern Ocean ecosystems: krill, the food-web and the impacts of harvesting // Biological Reviews of the Cambridge Philosophical Society. 2006. Vol. 81. Pp. 581-608. doi: 10.1017/ S1464793106007123.

26. Шунтов В.П., Темных О.С. Иллюзии и реалии экосистемного подхода к изучению и управлению морскими и океаническими биологическими ресурсами // Известия ТИНРО. 2013. Т. 173. С. 3-29.

27. АНТКОМ - управление Антарктикой. Хобарт: Изд-во АНТКОМ, 2001. 26 с. URL: https:// www.ccamlr.org/ru/node/73048 (дата обращения 30.07.2018).

28. Губанов Е.П., Бибик В.А. Ограничительные меры АНТКОМ на промысел криля // Рыбное хозяйство Украины. 2001. № 3-4. С. 8-10.

29. Губанов Е.П., Бибик В.А., Жук Н.Н. Промысел криля под угрозой введения жестких ограничений вылова // Рыбное хозяйство Украины. 2005. № 1. C. 20-22.

30. FitzPatrick T. Antarctic dumping grounds // RI's Environmental News Magazine Antarctica Series. 1997. URL: http://www.loe.org/shows/segments.html? programI=97-P13-00001\&segmentID=5 (дата обращения 20.07.2018).

31. Лукин В.В. К вопросу о национальной антарктической стратегии // Международная жизнь. 2018. № 1. URL: https://interaffairs.ru/jauthor/material/1963 (дата обращения 25.07.2018).

32. Лукин В.В. Предпосылки создания и современная роль Мадридского протокола в системе Договора об Антарктике // Проблемы Арктики и Антарктики. 2017. № 2 (112). С. 96-112.

33. Комиссия по сохранению морских живых ресурсов Антарктики CCAMLR-XXXII. Отчет тридцать второго совещания Комиссии (20-31 октября 2014 г.). Хобарт: Изд-во АНТКОМ, 2014. 271 с. URL: https://www.ccamlr.org/ru/system/files/r-cc-xxxiii_1.pdf (дата обращения 10.07.2018).

34. Wulff J. Regeneration of sponges in ecological context: is regeneration an integral part of life history and morphological strategies? // Integrative and Comparative Biology. 2010. Vol. 50. No 4. Pp. 494-505. doi:10.1093/ icb/icq100.

35. Долматов И.Ю., Бобровская Н.В., Гирич А.С. Иглокожие как модельные объекты для изучения 
механизмов регенерации // Вестник СПбГУ. 2014. Вып. 3. C. 96-112. URL: https://cyberleninka.ru/article/ n/iglokozhie-kak-modelnye-obekty-dlya-izucheniyamehanizmov-regeneratsii (дата обращения 21.02.2018).

36. Collie J.S., Hall S.J., Kaiser M.J., Poiner I.R. A quantitative analysis of fishing impacts on shelf-sea benthos // Journal of Animal Ecology. 2000. Vol. 69, issue 5. Pp. 785-798. doi: 10.1046/j.13652656.2000.00434.x.

37. Греков А.А., Павленко А.А. Сравнение ярусного и тралового донных видов промысла в Баренцевом море для разработки предложений по устойчивому использованию морских биоресурсов Баренцева моря // М.-Мурманск: Изд-во Всемирного фонда дикой природы (WWF), 2011. 54 с.

38. О решении по созданию морского охраняемого района (МОР) в море Росса. Брифинг официального представителя МИД России М.В. Захаровой // Прессслужба МИД РФ. 2016. URL: http://www.mid.ru/ press_service/spokesman/briefings/-/asset_publisher/ D2w $\bar{H}$ aWMCU6Od/content/id/2513436\#10 (дата обращения 18.07.2018).

39. Россия блокирует создание заповедников в Антарктике // РИА Новости. 2013. URL: https://ria.ru/ spravka/20131023/971577484.html (дата обращения 12.07.2018).

40. Артемьев А. Холодное море 2013-го. Россия вновь заблокировала создание двух гигантских морских заповедников в Антарктике // LENTA.RU. Мир. 2013. URL: https://enta.ru/articles/2013/11/07/antcom/ (дата обращения 22.07.2018).

41. China y Rusia bloquean creación de gran reserva marina en Antártida // El Universal.mx - Ciencia. 2014. URL: http://archivo.eluniversal.com.mx/ciencia/2014/ bloquean-creacion-reserva-antartida-96779.html (дата обращения 29.07.2018).

42. SC-CAMLR-IM-I/10 Rev. 1: Scientific background to the proposed East Antarctica Representative System of Marine Protected Areas // CCAMLR Meetings. 2013. URL: https://www.ccamlr.org/ru/sc-camlr-im-i/10-rev-1 (дата обращения 25.07.2018).

43. Hill S.L., Cavanagh R., Knowland C., Grant S., Downie R. The Last Ocean calls for protection of the entire Ross Sea, the most pristine marine ecosystem on Earth // The Last Ocean Education Resource. 2017. URL: http: //www.lastocean.org/ (дата обращения 30.07.2018).

44. Digges C. Small-scale US nuclear reactor blamed for spiking cancer rates, casting pall over Russia's FNPP fetish // Bellona. 2011. URL: http://bellona.org/news/ nuclear-issues/nuclear-usa/2011-03-small-scale-usnuclear-reactor-blamed-for-spiking-cancer-rates-castingpall-over-russias-fnpp-fetish (дата обращения 31.07.2018).

45. Robson S. New Zealand warns its Antarctic veterans about radiation risks from leaky US Navy reactor// Stars and Stripes. 2018. URL: https://www.stripes.com/news/ new-zealand-warns-its-antarctic-veterans-about- radiation-risks-from-leaky-us-navy-reactor-1.533546 (дата обращения 31.07.2018).

46. Bercovici S.K., Huber B.A., DeJong H.B., Dunbar R.B., Hansell D.A. Dissolved organic carbon in the Ross Sea: Deep enrichment and export // Limnology and Oceanography. 2017. Vol. 62, issue 6. Pp. 2593-2603. doi: 10.1002/lno.10592.

47. Петров А. Ученые: море Уэдделла в Антарктиде «заслуживает защиты» // Э-Вести. 2018. URL: http:// www.e-vesti.ru/ru/uch yon ye-more-ueddella-vantarktide-zasluzhivaet-zashhity/ (дата обращения 18.07.2018).

48. Garcia S.M., Cochrane K.L. Ecosystem approach to fisheries: a review of implementation guidelines // ICES Journal of Marine Science. 2005. Vol. 62, issue 3. Pp. 311-318. doi: 10.1016/j.icesjms.2004.12.003.

49. D'agata S., Mouillot D., Wantiez L., Friedlander A.M., Kulbicki M., Vigliola L. Marine reserves lag behind wilderness in the conservation of key functional roles // Nature Communications. 2016. No 7. doi: 10.1038/ ncomms 12000 .

\section{REFERENCES}

1. Aronson R.B., Thatje S., McClintock J.B., Hughes K.A. Anthropogenic impacts on marine ecosystems in Antarctica. Annals of the New York Academy of Sciences, 2011, no. 1223 (1), 82 p. doi: 10.1111/j.17496632.2010.05926.x.

2. Bridging the krill divide: Understanding cross-sector objectives for krill fishing and conservation. Report of an ICED-BAS-WWF workshop on understanding the objectives for krill fishing and conservation in the Scotia Sea and Antarctic Peninsula Region, held at WWF's Living Planet Centre, Woking, UK on $9^{\text {th }} \& 10^{\text {th }}$ June 2014. S. Hill, R. Cavanagh, C. Knowland, S. Grant, R. Downie. (Eds.). Cambridge: NERC Publ., 2014, 38 p. Available at: https://www.iced.ac.uk/documents/ Krill\%20divide\%20report_FINAL.pdf (accessed 29.07.2018).

3. Convey P., di Prisco G., Gutt E., Hodgson D., Mayewski P., Summerhayes C. Antarctic climate change and the environment. Antarctic Science, 2009, vol. 21, issue 6, pp. 541-563. doi: 10.1017/ S0954102009990642.

4. Tin T., Fleming Z., Hughes K., Ainley D., Convey P., Moreno C., Snape I. Impacts of local human activities on the Antarctic environment. Antarctic Science, 2009, no. 21 (1), pp. 3-33. doi: 10.1017/S0954102009001722.

5. Trathan P., Hill S., Belchier M., Grant S. Krill fishing and conservation in the Southern Ocean. British Antarctic Survey, 2018. Available at: https://www.bas.ac.uk/data/ our-data/publication/krill-fishing-and-conservation-inthe-southern-ocean/ (accessed 24.07.2018).

6. Fisheries and aquaculture software. FishStat J — software for fishery statistical time series. Available at: http:// 
www.fao.org/fishery/statistics/software/fishstatj/en (accessed 23.07.2018).

7. Promysel i stabil'nost' zapasov krilya [Krill fisheries and sustainability]. Promysly CCAMLR [CCAMLR Fisheries], 2018. Available at: https:/www.ccamlr.org/ ru/fisheries/промысел-и-стабильность-запасов-криля (accessed 06.07.2018). (In Russian).

8. Bizikov V.A. Itogi XXXII soveshchaniya ANTKOM: pochemu strany ne mogut dogovorit'sya o sozdanii morskikh okhranyaemykh rayonov v Antarktike? [Results of the XXXII CCAMLR meeting: Why cannot the countries come to an agreement on the issue of creation of marine protected areas in the Antarctic?]. VNIRO International Cooperation, 2013. Available at: http:// www.vniro.ru/ru/novosti/novosti-2013/itogi-xxxiisoveshchaniya-antkom-pochemu-strany-ne-mogutdogovoritsya-o-sozdanii-morskikh-okhranyaemykhrajonov-v-antarktike (accessed 18.07.2018). (In Russian).

9. Kolesnikova E.A. Antarktika: istoriya osvoeniya i perspektivy [Antarctica: The history of exploration and prospects]. Vestnik Moskovskogo universiteta [Moscow State University Bulletin], 2015, no. 4, pp. 182-203. Available at: http://fmp.msu.ru/attachments/article/361/ KOLESNIKOVA_2015_4.pdf (accessed 21.07.2018). (In Russian).

10. Shust K.V. O mezhdunarodnoy deyatel'nosti VNIRO i basseynovykh rybokhozyaystvennykh institutov v sfere ratsional'nogo ispol'zovaniya morskikh zhivykh resursov Antarktiki [International activities of VNIRO and regional fishery research institutes in rational utilization of the living marine resources of the South Ocean]. Trudy VNIRO [VNIRO Proceedings], 2005, vol. 145, pp. 113122. (In Russian).

11. Atkinson A., Fielding S., Schmidt K., Venables H., Enderlein P., Schlosser C., Achterberg E., Patey M. The role of krill in Southern Ocean nutrient cycles: fieldwork report (Season 2010/2011). In: British Antarctic Survey. JCR Cruise. JR245/JR246/JR247: Western Core Box, the role of krill grazing in Southern Ocean nutrient cycles, and AFI-CGS Individual physiological and behavioural responses of krill to distributional shifts and thermal change. Cambridge: NERC Publ., 2011, pp. 5972. Available at: https://www.bodc.ac.uk/resources/ inventories/cruise_inventory/reports/jr245.pdf(accessed 06.07.2018).

12. Shust K.V., Bizikov V.A. Rol' SSSR i Rossii v formirovanii mezhdunarodnogo pravovogo rezhima sokhraneniya i ratsional'nogo ispol'zovaniya morskikh bioresursov Antarktiki [Role of the USSR and Russia in development of international legal regime for preservation and rational utilization of marine living resources of the Antarctic]. Trudy VNIRO [VNIRO Proceedings], 2010, vol. 149, pp. 438-451. (In Russian).

13. Shust K.V., Bizikov V.A. Izuchenie i promyslovoe osvoenie biologicheskikh resursov Antarkticheskikh vod [Research and commercial development of bioresources of the Antarctic waters]. Voprosy rybolovstva [Problems of Fisheries], 2010, vol. 11, no. 4 (44), pp. 765-779. (In Russian).

14. Korzun V.A. Otsenka vozmozhnostey ispol'zovaniya resursov Antarktiki [Estimation of opportunities of use of resources of Antarctic]. Moscow: IMEMO RAS Publ., 2009, 116 p. Available at: https://docplayer.ru/27328238V-a-korzun-ocenka-vozmozhnostey-ispolzovaniyaresursov-antarktiki.html (accessed 06.07.2018). (In Russian).

15. Final Act of the Conference for the Conservation of Antarctic Marine Living Resources, Canberra, Australia, 7-20 May, 1980. Available at: https:/www.ccamlr.org/ en/system/files/Conference $\% 20$ on $\% 20$ the $\% 20$ Conservation $\% 20$ of $\% 20$ Antarctic $\% 20$ Marine $\% 20$ Living\%20Resources.pdf(accessed 24.07.2018).

16. Samyshev E.Z. Antarkticheskiy kril' i struktura soobshchestva $\mathrm{v}$ ego areale [Antarctic krill and the structure of planktonic community in its distribution area]. Moscow: Nauka [Science], 1991, 168 p. (In Russian).

17. Constable A.J. The ecosystem approach to managing fisheries: achieving conservation objectives for predators of fished species. CCAMLR Science, 2001, vol. 8, pp. 37-64.

18. About CCAMLR. Conserving Antarctic marine life. Available at: https://www.ccamlr.org/en/organisation (accessed 12.07.2018).

19. Hinke J.T., Cossio A.M., Goebel M.E., Reiss C.S., Trivelpiece W.Z., Watters G.M. Identifying risk: Concurrent overlap of the Antarctic krill fishery with krilldependent predators in the Scotia Sea. PLOS ONE, 2017, no. 12 (1). doi: 10.1371/journal.pone.0170132.

20. Atkinson A., Nicol S., Kawaguchi S., Pakhomov E., Quetin L., Ross R., Hill S., Reiss C., Siegel V. Fitting Euphausia superba into Southern Ocean food-web models: a review of data sources and their limitations. CCAMLR Science, 2012, vol. 19, pp. 219-245. Available at: https:/www.ccamlr.org/en/system/files/ science_journal_papers/Atkinson-krill.pdf (accessed 30.07.2018).

21. Constable A.J. Lessons from CCAMLR on the implementation of the ecosystem approach to managing fisheries. Fish and Fisheries, 2011, vol. 12, issue 2, pp. 138-151. doi: abs/10.1111/j.14672979.2011.00410.x.

22. Constable A.J., de la Mare W.K., Agnew D.J., Everson I., Miller D. Managing fisheries to conserve the Antarctic marine ecosystem: practical implementation of the Convention on the Conservation of Antarctic Marine Living Resources (CCAMLR). ICES Journal of Marine Science, 2000, no. 57, pp. 778-791.

23. Garcia S.M., Rosenberg A.A. Food security and marine capture fisheries: characteristics, trends, drivers and 
future perspectives. Philosophical Transactions of the Royal Society. Biological Sciences, 2010, no. 365, pp. 2869-2880. doi: 10.1098/rstb.2010.0171.

24. Gascón V., Werner R. CCAMLR and Antarctic krill: Ecosystem management around the great white continent. Ocean \& Fisheries Law, 2006, vol. 7, issue 1, pp. 14-16. Available at: http://digitalcommons. wcl.american.edu/cgi/viewcontent.cgi? article $=1198 \&$ context $=$ sdlp $($ accessed 24.07.2018).

25. Hill S.L., Murphy E.J., Reid K., Trathan P.N., Constable A.J. Modelling Southern Ocean ecosystems: krill, the food-web and the impacts of harvesting. Biological Reviews of the Cambridge Philosophical Society, 2006, vol. 81, pp. 581-608. doi: 10.1017/ S1464793106007123.

26. Shuntov V.P., Temnykh O.S. Illyuzii i realii ekosistemnogo podkhoda $\mathrm{k}$ izucheniyu i upravleniyu morskimi i okeanicheskimi biologicheskimi resursami [Illusions and realities of ecosystem approach to study and management of marine and oceanic biological resources]. Izvestiya TINRO [Transactions of the Pacific Research Institute of Fisheries and Oceanography], 2013, vol. 173, pp. 3-29. (In Russian).

27. ANTKOM - upravlenie Antarktikoy [CCAMLR's Management of the Antarctic]. Hobart: CCAMLR Publ., 2001, 26 p. Available at: https://www.ccamlr.org/ru/node/ 73048 (accessed 30.07.2018). (In Russian).

28. Gubanov E.P., Bibik V.A. Ogranichitel'nye mery ANTKOM na promysel krilya [CCAMLR's restrictive measures for krill harvesting]. Rybnoe khozyaystvo Ukrainy [Fishing Industry of Ukraine], 2001, no. 3-4, pp. 8-10. (In Russian).

29. Gubanov E.P., Bibik V.A., Zhuk N.N. Promysel krilya pod ugrozoy vvedeniya zhestkikh ogranicheniy vylova [Krill harvesting under the threat of implementation of strict catch limitations]. Rybnoe khozyaystvo Ukrainy [Fishing Industry of Ukraine], 2005, no. 1, pp. 20-22. (In Russian).

30. FitzPatrick T. Antarctic dumping grounds. RI's Environmental News Magazine Antarctica Series, 1997. Available at: http://www.loe.org/shows/ segments.html?programID=97-P13-00001\&segment $\mathrm{ID}=5$ (accessed 20.07.2018).

31. Lukin V.V. K voprosy o natsional'noy antarkticheskoy strategii [On the issue of national Antarctic strategy]. Mezhdunarodnaya zhizn' [International Affairs], 2018, no. 1. Available at: https://interaffairs.ru/jauthor/material/ 1963 (accessed 25.07.2018). (In Russian).

32. Lukin V.V. Predposylki sozdaniya i sovremennaya rol' Madridskogo protokola v sisteme Dogovora ob Antarktike [Historical background and current role of the Madrid Protocol within the framework of the Antarctic Treaty]. Problemy Arktiki i Antarktiki [Arctic and Antarctic Research], 2017, no. 2 (112), pp. 96-112. (In Russian).

33. Komissiya po sokhraneniyu morskikh zhivykh resursov Antarktiki CCAMLR-XXXII. Otchet tridtsat' vtorogo soveshchaniya Komissii (20-31 oktyabrya 2014 g.) [CCAMLR-XXXII. Commission for the Conservation of Antarctic Marine Living Resources. Report of the thirty-second meeting of the Commission (20-31 October, 2014)]. Hobart: CCAMLR Publ., 2014, 271 p. Available at: https://www.ccamlr.org/ru/system/files/r-ccxxxiii_1.pdf(accessed 10.07.2018). (In Russian).

34. Wulff J. Regeneration of sponges in ecological context: is regeneration an integral part of life history and morphological strategies? Integrative and Comparative Biology, 2010, vol. 50, no. 4, pp. 494-505. doi:10.1093/ icb/icq100.

35. Dolmatov I.Yu., Bobrovskaya N.V., Girich A.S. Iglokozhie kak model'nye ob"ekty dlya izucheniya mekhanizmov regeneratsii [Echinoderms as model objects for study of regeneration mechanisms]. Vestnik $S P b G U$ [Bulletin of Saint-Petersburg State University], 2014, issue 3, pp. 96-112. Available at: https:// cyberleninka.ru/article/n/iglokozhie-kak-modelnyeobekty-dlya-izucheniya-mehanizmov-regeneratsii (accessed 21.02.2018). (In Russian).

36. Collie J.S., Hall S.J., Kaiser M.J., Poiner I.R. A quantitative analysis of fishing impacts on shelf-sea benthos. Journal of Animal Ecology, 2000, vol. 69, issue 5, pp. 785-798. doi: $10.1046 / \mathrm{j} .1365-$ 2656.2000.00434.x.

37. Grekov A.A., Pavlenko A.A. A comparison of longline and trawl fishing practices and suggestions for encouraging the sustainable management of fisheries in the Barents Sea. Moscow-Murmansk: World Wide Fund for Nature (WWF) Publ., 2011, 50 p.

38. O reshenii po sozdaniyu morskogo okhranyaemogo rayona (MOR) v more Rossa. Brifing ofitsial'nogo predstavitelya MID Rossii M.V. Zakharovoy [On the decision to create a marine protected area (MPA) in the Ross Sea. Briefing of the spokesperson of the Ministry of Foreign Affairs of the Russian Federation M.V. Zakharova]. Press-sluzhba MID RF [Press Service of the MFA RF], 2016. Available at: http://www.mid.ru/ press_service/spokesman/briefings/-/asset_publisher/ D2wHaWMCU6Od/content/id/2513436\#10 (accessed 18.07.2018). (In Russian).

39. Rossiya blokiruet sozdanie zapovednikov v Antarktike [Russia obstructs the creation of reserves in the Antarctic]. RIA Novosti [RIA News], 2013. Available at: https://ria.ru/spravka/20131023/971577484.html (accessed 12.07.2018). (In Russian).

40. Artem'ev A. Kholodnoe more 2013-go. Rossiya vnov' zablokirovala sozdanie dvukh gigantskikh morskikh zapovednikov v Antarktike [The cold sea of 2013. Once again, Russia banned the creation of two large marine reserves in the Antarctic]. LENTA.RU. Mir [LENTA.RU. World], 2013. Available at: https://enta.ru/articles/2013/ 11/07/antcom/ (accessed 22.07.2018). (In Russian).

41. China y Rusia bloquean creación de gran reserva marina en Antártida. El Universal.mx - Ciencia, 2014. Available at: http://archivo.eluniversal.com.mx/ciencia/2014/ 
bloquean-creacion-reserva-antartida-96779.html (accessed 29.07.2018). (In Spanish).

42. SC-CAMLR-IM-I/10 Rev. 1: Scientific background to the proposed East Antarctica Representative System of Marine Protected Areas. CCAMLR Meetings, 2013. Available at: https://www.ccamlr.org/ru/sc-camlr-im-i/ 10-rev-1 (accessed 25.07.2018).

43. Hill S.L., Cavanagh R., Knowland C., Grant S., Downie R. The Last Ocean calls for protection of the entire Ross Sea, the most pristine marine ecosystem on Earth. The Last Ocean Education Resource, 2017. Available at: http://www.lastocean.org/ (accessed 30.07.2018).

44. Digges C. Small-scale US nuclear reactor blamed for spiking cancer rates, casting pall over Russia's FNPP fetish. Bellona, 2011. Available at: http://bellona.org/ news/nuclear-issues/nuclear-usa/2011-03-small-scale-usnuclear-reactor-blamed-for-spiking-cancer-rates-castingpall-over-russias-fnpp-fetish (accessed 31.07.2018).

45. Robson S. New Zealand warns its Antarctic veterans about radiation risks from leaky US Navy reactor. Stars and Stripes, 2018. Available at: https://www.stripes.com/ news/new-zealand-warns-its-antarctic-veterans-aboutradiation-risks-from-leaky-us-navy-reactor-1.533546 (accessed 31.07.2018).
46. Bercovici S.K., Huber B.A., DeJong H.B., Dunbar R.B., Hansell D.A. Dissolved organic carbon in the Ross Sea: Deep enrichment and export. Limnology and Oceanography, 2017, vol. 62, issue 6, pp. 2593-2603. doi: 10.1002/lno.10592.

47. Petrov A. Uchenye: more Ueddella v Antarktide "zasluzhivaet zashchity" [Scientists: The Weddell Sea in Antarctica "deserves protection"]. E-Vesti, 2018. Available at: http://www.e-vesti.ru/ru/uchyonye-moreueddella-v-antarktide-zasluzhivaet-zashhity/ (accessed 18.07.2018). (In Russian).

48. Garcia S.M., Cochrane K.L. Ecosystem approach to fisheries: a review of implementation guidelines. ICES Journal of Marine Science, 2005, vol. 62, issue 3, pp. 311-318. doi: 10.1016/j.icesjms.2004.12.003.

49. D'agata S., Mouillot D., Wantiez L., Friedlander A.M., Kulbicki M., Vigliola L. Marine reserves lag behind wilderness in the conservation of key functional roles. Nature Communications, 2016, no. 7. doi: 10.1038/ ncomms 12000.

Поступила 09.08.2018

Принята к печати 14.09.2018 